COLIN LAWRENCE

Columbia University

ROBERT Z. LAWRENCE

Brookings Institution

\title{
Manufacturing Wage \\ Dispersion: An End Game Interpretation
}

OVER THE PAST FIFTEEN YEARS there has been an extraordinary increase in the dispersion of wages among manufacturing industries in the United States. While there were moderate cyclical swings in the coefficient of variation of hourly wages between 1955 and 1970 , there was no obvious trend in this indicator of dispersion. ${ }^{1}$ Yet between 1970 and 1984, it increased by about a third, ${ }^{2}$ reflecting primarily an increase in relative wages in high-wage industries. In a sample of average hourly earnings in fifty-seven manufacturing industries (at the three-digit SIC level), the

This paper was funded in part by grants from the Ford Foundation and the National Science Foundation. The authors are grateful to Paula R. DeMasi for superb research assistance; to Kenreth D. Boese and Edward Gardner for comments; and to Charlotte Kaiser, Kirk W. Kimmell, and Evelyn M. E. Taylor for text processing.

1. For evidence on the long-run stability of interindustry wages, see Donald E. Cullen, “The Interindustry Wage Structure 1899-1950," American Economic Review', vol. 46 (June 1956), pp. 353-69.

2. Michael L. Wachter and William L. Wascher, "Labor Market Policies in Response to Structural Changes in Labor Demand," in Federal Reserve Bank of Kansas City, Industrial Change and Public Policy (FRBK, 1983), pp. 177-2!6. According to Wachter and Wascher, the coefficient of variation of average hourly manufacturing wages was 17.52 in 1955, 18.73 in 1960, 17.01 in 1970, 20.44 in 1975, 22.61 in 1980, and 24.05 in 1982. The data sample used for this study indicates similar behavior. The coefficient of variation in average hourly earnings was 17.31 in $1960,16.26$ in 1970, 21.38 in 1980, 22.10 in 1982, and 22.11 in 1984. 
correlation between wage levels in 1970 and wage changes between 1970 and 1984 was $0.37 .{ }^{3}$ Over the decade of the 1970 s, for example, the compensation of steel and auto workers increased 30 and 15 percent more, respectively, than did the sample average. Union wages rose 11 percent more than did nonunion wages in the U.S. manufacturing sector overall.

The growing wage differential between high- and low-wage industries has been the subject of considerable debate. It has been perceived as a major structural problem for three reasons. First, the fact that the premiums paid to U.S. steel and automobile workers over the manufacturing average are substantially higher than the premiums paid to their Japanese counterparts is seen as a major cause of declining U.S. international competitiveness in these industries. ${ }^{4}$ Second, the size of the differential implies substantial costs for workers displaced from highwage industries and provides workers with considerable incentives to avoid displacement by promoting trade protection or industry subsidies. Finally, the size of the differential means that workers who are displaced from high-wage industries are likely to delay seeking and accepting alternative employment in the hope of being recalled. ${ }^{5}$

Because industries differ in the demographic composition of their labor force, the growing dispersion in industrial wages could reflect shifts in the wages associated with demographic characteristics. ${ }^{6}$ The relationship between work-force characteristics and the relative wages of workers with these characteristics is fairly straightforward. If workers of different ages, education, and sex are imperfect substitutes for one

3. Greater than 0.265 is statistically significant at the 5 percent level.

4. See, for example, Jose A. Gomez-Ibanez and David Harrison, Jr., "Imports and the Future of the U.S. Automobile Industry," American Economic Review', vol. 72 (May 1982, Papers and Proceedings, 1981), pp. 319-23; Richard G. Anderson and Mordechai E. Kreinen, "Labour Costs in the American Steel and Auto Industries," The World Economy, vol. 4 (June 1981), pp. 199-208.

5. See Wachter and Wascher, "Labor Market Policies," p. 179.

6. The growing industry-wage dispersion in the United States as compared with the relatively constant dispersion in Europe has been interpreted as an indicator of the flexibility of the U.S. labor market and has led some observers to link these differences to the superior U.S. employment performance over the decade. See Manfred Wegner, "The Employment Miracle in the United States and Stagnating Employment in the European Community-a Tentative Explanation,"' Economic Papers, 17 (Brussels: Commission of the European Communities, July 1983). For further discussion of labor market flexibility, see OECD Employment Outlook (Paris: OECD, September 1984), pp. 13-29. 
another, relatively rapid growth in the availability of workers with particular characteristics will lower their relative wages. Industries with such workers will experience a decline in their relative wages. In the empirical analysis below, we take account of these effects in explaining relative wage behavior.

The relationship between union behavior and wage changes is more complex. Economic theory suggests that union workers will have relatively higher wages than nonunion workers, but not that their relative wages will rise over time. Yet that is precisely what occurred during the 1970s. In fact, the wage increases contradicted the conventional wisdom in a number of different ways. The accepted theory of union behavior in concentrated industries suggests that unions are able to capture some excess profits in the presence of entry barriers. On this theory, the 1970s, a period with unusually low rates of profitability, should not have seen rising relative union wages. Similarly, unions might be expected to raise wages in response to increases in labor demand, but employment and demand in numerous heavily unionized industries grew relatively slowly over the decade. Finally, unions might be expected to raise wages to capture increased returns from improvements in international competitiveness, but in numerous heavily unionized sectors, competitive pressures from abroad increased over the 1970s. Indeed, both the steel and automobile industries were marked by all three characteristics: declining profitability, slower demand growth, and declining international competitiveness. ${ }^{7}$ Why, then, did relative wages in these sectors rise?

The existing explanations are unsatisfactory. One stresses an unwarranted adherence by union leaders to traditional wage-setting strategies. Union wage agreements are routinely specified in terms of a cost-ofliving adjustment (COLA) to compensate for inflation, plus a reward for higher productivity. During the 1970s, however, supply-side shocks disturbed the traditional relationship between inflation and warranted wage growth. Real wages should have been lowered to reflect those external shocks in the terms of trade, but the COLA-plus contracts

7. Ann C. Orr and James A. Orr, "Job Cuts Are Only One Means Firms Use to Counter Imports," Monthly Labor Review, vol. 107 (June 1984), pp. 39-41. Orr and Orr studied adjustment behavior in twenty-five import-sensitive industries. They found that relative wage declines were common, but that the automobile and steel industries were anomalies in their pattern of adjustment. 
inhibited such adjustment. Relative union wages therefore increased beyond levels that perfect foresight might have permitted. It is true that unanticipated inflation could temporarily disturb relative wage differentials over the course of one contract. But the theory does not explain why, when contracts are reopened for negotiation, management is unable to obtain recognition that wages have moved beyond the levels originally anticipated.

A second explanation for the rise in relative union wages is that union wages are often set in three-year contracts, whereas nonunion wages are typically adjusted annually. ${ }^{8}$ Average union wages are thus less responsive to cyclical conditions. But while differences in cyclical responses may account for short-run shifts in the union-nonunion premium, they are scarcely adequate to account for a decade-long shift. Richard B. Freeman and James L. Medoff make the cyclical interpretation somewhat more plausible by conjecturing that some of the rise in the union premium may be due to the timing of major collective agreements in the 1970s, with more workers covered by contracts signed in the relatively good years of 1973,1976 , and 1979, than in recession years. ${ }^{9}$ However, Daniel J. B. Mitchell has found that the rate of unemployment prevailing at the time of contract negotiation has no significant influence on the magnitude of wage increases over entire three-year contracts. ${ }^{10}$ Finally, if union wages are cyclically unresponsive, the gap between union and nonunion wages should narrow in expansions. Yet in each year of the expansion between 1975 and 1979, union wages increased more rapidly than did nonunion wages. ${ }^{11}$

8. For a theoretical treatment of the cyclical behavior of the union-nonunion wage differential, see Ian M. McDonald and Robert M. Solow, "Wages and Employment in a Segmented Labour Market," Economic Discussion Paper 76 (Department of Applied Economics, University of Cambridge, January 1984).

9. Richard B. Freeman and James L. Medoff, What Do Unions Do? (Basic Books, 1984), p. 54.

10. See Daniel J. B. Mitchell, "Union Wage Determination: Policy Implications and Outlook," BPEA, 3:1978, pp. 537-82.

11.

Union-nonunion wage ratio in manufacturing

$\begin{array}{llllll}1970 & 0.91 & 1975 & 0.94 & 1980 & 1.01 \\ 1971 & 0.92 & 1976 & 0.95 & 1981 & 1.01 \\ 1972 & 0.92 & 1977 & 0.96 & 1982 & 1.02 \\ 1973 & 0.93 & 1978 & 0.97 & 1983 & 1.01 \\ 1974 & 0.93 & 1979 & 0.98 & 1984 & 1.00\end{array}$

Calculated from the U.S. Bureau of Labor Statistics, Employment Cost Index for 197684, and from George Ruben, "Observations of Wage Developments in Manufacturing during 1959-78, 'C Current Wage Developments, vol. 33 (May 1981), p. 53. 
A third explanation for relative union wage increases blames quota protection. It is true that removing or constraining foreign competitors could reduce the incentives for domestic firms to restrain labor costs. But while this explanation provides some insights into some industries over some periods, it is unlikely to account for much of the story over the 1970s. The automobile industry received no formal trade protection until the voluntary restraint agreement with Japan in 1981. The steel industry was protected only intermittently and between 1977 and 1981 by a trigger price system that was unlikely to have had a major impact on the demand for steel labor. Moreover, many industries with rising wages received no increases in protection.

A fourth line of reasoning suggests that it is necessary to examine industry-specific factors in detail. As Wachter and Wascher conclude, "Institutional and industry-specific factors and information lags probably explain some of the inability of firms to adjust relative wages. One example is the steel industry's experimental no-strike agreement."'12 Yet, as we will demonstrate, the increased wage dispersion is not simply a story of steel or automobile wages. It reflects more widespread phenomena that suggest a common cause rather than industry-specific factors.

It seems fair to conclude that the literature has yet to provide an adequate account of relative wage behavior. ${ }^{13}$ This paper attempts to provide a more satisfactory explanation.

The novel part of the analysis rests on a theory that predicts rising union wage differentials in the face of long-run declines in demand growth. We model a monopoly union maximizing the expected utility of its members. Just as monopolists in the product market take account of the demand elasticity for their product in setting its price, so monopoly unions take account of the elasticity of the derived demand for union labor in making their wage demands. The derived demand for union labor is in turn a function of the demand for the final product and the substitution possibilities between union labor and other factors of production. The greater the elasticity of substitution, the greater the displacement of workers for a given wage increase. Everything else being equal, therefore, union wages should rise when a disturbance lowers the elasticity of labor demand. Higher union wages could there-

12. Wachter and Wascher, "Labor Market Policies," p. 189.

13. For a similar view, see Freeman and Medoff, What Do Unions Do?, p. 54. 
fore result either from a decline in product demand elasticities or from a decline in substitution elasticities.

Our explanation stresses a decline in the substitution possibilities between labor and capital brought about by slower growth. The elasticity of labor demand will generally be greater for expansions in production, for which ex ante substitution possibilities are relevant (putty-putty), than for contractions of production, for which ex post, or short-run, substitution possibilities are relevant (putty-clay). In industries with "lumpy" (that is, large and immobile) capital, disturbances that reduce investment and increase the share of production expected to be undertaken with the existing capital lower the potential for capital-labor substitution.

Given large amounts of long-lived industry-specific capital, therefore, declines in the growth of demand could lower the elasticity of labor demand for a substantial period of time. In an extreme case, the "end game," further investment becomes permanently undesirable, and only ex post substitution possibilities are relevant. In such circumstances, unions may seek to "harvest" the quasi-rents earned by capital before the owners do. ${ }^{14}$ We will argue that during the 1970s the U.S. steel industry was in an end game and that relative steel wages behaved accordingly.

Most U.S. heavy industries were not in an end game during the 1970 s. They were, however, in an overall economy in which long-run economic growth had slowed. To account for their wage behavior, we will apply the more general theory about union wage behavior under conditions of slower growth-the slow game.

The first section of the paper outlines the theories of end game and slow game. The second section examines steel wage behavior as a test of end game. To test the slow game hypothesis, the third section examines wage behavior across fifty-seven U.S. manufacturing industries over the last two decades. The fourth section examines the puzzling decline in total-factor productivity growth across the U.S. economy since 1973, and suggests that productivity growth may decline in the face of slow game situations. The paper concludes by considering further applications and implications.

14. Kathryn Rudie Harrigan and Michael E. Porter, "End-game Strategies for Declining Industries," Harvard Business Review, vol. 61 (July-August 1983), pp. 111-20. 


\section{Wages in Declining Industries: End Game and Slow Game}

The conventional expectation of a positive relationship between union wages and industry profits ignores the peculiar impact of slower and declining growth on union power in industries with substantial amounts of long-lived capital. In this section we contrast union wage responses to declining demand in the presence of short- and long-lived capital. We analyze union wages in response to a disturbance requiring permanent capacity reductions - the end game-and in response to declines in capacity growth-the slow game. We also discuss extensions and qualifications.

\section{LONG-RUN WAGE BARGAINS}

We begin by laying out our model and exploring union wage determination in response to declining demand in an industry where capital is mobile or short-lived. In this case wages conform to the conventional expectation of a decline (or no change). Wages can rise, however, in response to declining demand in cases where capital is industry-specific and long-lived.

An industry produces a product that is an imperfect substitute for those produced in other nations. Production is organized under perfect competition so that while each domestic firm faces a perfectly elastic demand curve, industrywide production can influence the international price; that is, the domestic industry faces a downward sloping demand curve. Output is produced with two inputs, labor and capital. Capital markets are competitive, while the industry faces a union with a monopoly over the supply of labor. The union sets the wage rate at which labor is supplied to all domestic firms. We follow Ian M. McDonald and Robert M. Solow (M-S) in modeling the determination of the union wage rate. ${ }^{15}$ The union chooses the point on the industry's aggregate derived demand schedule for labor that maximizes the expected utility of its members.

15. See Ian M. McDonald and Robert M. Solow, "Wage Bargaining and Employment," American Economic Review, vol. 71 (December 1981), pp. 896-908. Most of the results presented here would apply to other typical specifications of union utility functions. 
Union membership is fixed at $N$. If $L$ members are employed, each member has a probability of $L / N$ of a unionized job with a utility of $U(w)$ and a probability of $1-L / N$ of a job elsewhere (or unemployment compensation) with utility $U(\bar{w})$, where $\bar{w}$ is the economywide reservation wage, which is assumed constant throughout the analysis. ${ }^{16}$ The expected utility function of any individual member is thus

$$
\frac{L}{N} U(w)+\left(1-\frac{L}{N}\right) U(\bar{w}) .
$$

Assuming that the aggregate union expected welfare function is summable over its $N$ members, the union seeks to maximize

$$
L(U(w)-\bar{U}),
$$

where $\bar{U}=U(\bar{w})$, subject to the aggregate derived demand schedule for labor in industry $Y$.

The production technology is given by a Constant Elasticity of Substitution (CES) production function,

$$
Y=\left[\alpha L^{\rho}+(1-\alpha) K^{\rho}\right]^{1 / \rho}-\infty \leqq \rho \leqq 1,
$$

where $L$ and $K$ are labor and capital inputs and $\alpha$ and $\rho$ are production parameters. The elasticity of the substitution between capital and labor, $\sigma$, is equal to $1 /(1-\rho)$.

The first order conditions for each firm's optimization are

$$
w=\alpha P Y^{1-\rho} L^{\rho-1}
$$

and

$$
\frac{w}{r}=\left(\frac{\alpha}{1-\alpha}\right)\left(\frac{L}{K}\right)^{\rho-1},
$$

where $r$ is the rental price of capital. The aggregate demand curve facing the entire industry is given by

$$
P=\mathrm{Z} Y^{-1 / \beta} e^{(1 / \beta) V}, \text { where } \mathrm{Z}, \beta>0 .
$$

$P$ is the international product price, $\beta$ is the constant elasticity of demand,

16. For a general equilibrium analysis of this problem, see John K. Hill, "Comparative Statics in General Equilibrium Models with a Unionized Sector,' Journal of International Economics, vol. 16 (August 1984), pp. 345-56. 
and $V$ is a stochastic demand shifter. ${ }^{17}$ For example, a negative $V$ could represent either a decline in international competitiveness (foreign firms produce substitute goods at lower costs) or a shift in either domestic or foreign demand. The derived demand for labor can be found by substituting equations 3,5 , and 6 into equation 4 . In logs this is

$$
\begin{aligned}
\log w=A & +\frac{1}{\rho}\left(\frac{1}{\sigma}-\frac{1}{\beta}\right) \log \left[\alpha+(1-\alpha)\left(\frac{1-\alpha}{\alpha} \cdot \frac{w}{r}\right)^{\rho \sigma}\right] \\
& -\beta^{-1} \log L+\beta^{-1} V,
\end{aligned}
$$

where $A$ is a constant. The elasticity of labor with respect to wages is the Hicksian long-run derived demand elasticity, $\eta^{L}$, which is a function of the elasticities of demand, $\beta$, and substitution, $\sigma$ :

$$
\begin{aligned}
\eta^{L} & \equiv \sigma(1-S)+S \beta, \\
\text { where } S & =\left[1+\frac{1-\alpha}{\alpha}\left(\frac{1-\alpha}{\alpha} \frac{w}{r}\right)^{\rho \sigma}\right]^{-1} \text { is the share of labor. }
\end{aligned}
$$

The union chooses $w$ and $L$ so as to maximize function 2 subject to equation 7 . The optimum condition is

$$
\frac{U^{\prime}(w) w}{U(w)-\bar{U}}=\eta
$$

The union equates the elasticity of the gain in utility from employment in the industry (with respect to the wage rate) with the elasticity of derived demand, $\eta$. Thus as with monopoly in the product market, : crucial consideration for the monopoly union is $\eta$.

Consider now a permanent inward shift in the product demand curve due to the availability of cheaper foreign or domestic substitutes, changes in tastes, or reductions in income. This shock does not change the derived elasticity of demand for labor shown in equilibrium condition 9 for a given wage rate. Given the specification of the M-S utility function, the CES production function, and the demand shock, therefore, the wage rate sought by the union will remain unchanged. Wages remain constant, and, since the rental rate is fixed, the adjustment takes the form of an equiproportional reduction in labor and capital. If, however,

17. Commercial policy (for example, quotas) or changes in international competitiveness could also change $\beta$. 
inward demand shifts alter the elasticity of derived demand, they could reduce both wages and the capital-labor ratio. ${ }^{18}$

A central assumption of this model is mobile or short-lived capital. The decline in the demand curve does not alter the substitution possibilities between capital and labor. Ex post and ex ante capital is puttyputty. Capital must always earn a normal rate of return and will, therefore, be reduced, along with employment, until the marginal unit of capital earns the economywide rental rate. If capital is extremely short-lived in relation to the contract period, the use of the putty-putty assumption may be valid, but what is the response to a declining demand curve in industries such as steel, oil, and shipbuilding, where capital is long-lived and industry-specific? Over significant ranges of output, the response to declines in demand in such cases will simply be a higher level of unutilized capacity. Under these circumstances, therefore, unless scrapped, capital will only "leave" the industry as it wears out. Under such conditions, a shock that reduces the desired capital stock could appreciably lower the elasticity of demand for labor and raise wages. Thus, in the face of common downward shifts in demand, depending upon the nature of the capital stock, wages could behave differently in different industries, and the dispersion in wages could rise.

\section{THE END GAME}

Consider an extreme example in which capital equipment, once installed, is infinitely long-lived, and in which the union is faced with a permanent reduction in the product demand curve. Even if the union were to set wages as low as $\bar{w}$, the industry would not add new capital. Scrapping, however, will occur only when revenue falls below variable costs.

18. This conforms to the conventional expectation of a positive association between demand shifts and wages. See, for example, Oded Galor, "Labor Union Objectives and Optimal Wage Policy in a Dynamic Setting," in Three Essays in Economic Theory (Ph.D. dissertation, Columbia University, May 1984). See also Michael A. Salinger, "Tobin's $q$, Unionization, and the Concentration-Profits Relationship," Rand Journal of Economics, vol. 15 (Summer 1984), pp. 159-70. Salinger argues that in imperfectly competitive product markets where firms earn normal profits, unions will be forced to accept wage cuts so as to insure that firms will continue investing in the industry (that is, the value of the firm relative to replacement costs-Tobin`s $q$-remains above unity). 
A Special Case. Before proceeding to a general analysis of end game, we examine the special case where ex post there are no substitution possibilities between capital and labor $(\sigma=0)$-that is, there is a Leontief technology for each plant in the industry. If output is varied ex post, it must be done by changing factors in fixed proportions. Assume that output, labor, and capital are measured in units such that at the initial equilibrium, one unit of capital and one of labor are required to produce one unit of output. Thus both output and labor input can be read off along the $X$ axis as illustrated in figure 1. Initially, facing a derived demand curve $D_{L}^{*}$, the union sets a wage $w^{*}$ resulting in $Q^{*}$ units of output being produced, with $L^{*}$ and $K^{*}$ as inputs (point $A$ ). As indicated in the lower panel, the price will be $P^{*}$, the price associated with $Q^{*}$ on the product demand curve $D^{*}$. Of course, the union could choose a point like $B$ on the short-run curve $D_{S}^{*} B L^{*}$, but to do so would be to inhibit any further investment in the industry.

Suppose there is an unanticipated permanent decline in product demand, shifting the demand curve to $D_{1} .{ }^{19}$ Suppose further that firms now find that capacity expansion has a negative net present value. ${ }^{20}$ Since no investment will take place, higher wages have no opportunity cost in the form of reduced investment. The union now selects a point on the kinked short-run derived demand curve $D_{S}^{1} C L^{*}$. Along the segment $C L^{*}$, all plants will remain open, whereas on segment $D_{S}^{!} C$, some plants will be forced to shut down. ${ }^{21}$ Along $C L^{*}$, the curve is perfectly inelastic until $C$, at which point the wage bill exhausts total revenue for all homogeneous plants. At wages higher than $w_{1}$ (that is, point $C$ ), some plants will shut down, and wages for the entire industry exhaust revenues. If the union chooses $C$, all plants will remain in business, the wage rate $w_{1}$ will be equal to the price $P_{1}$, and the union will have appropriated all the profits without losing any employment. For owners of plants, the return has been reduced to zero. Thus in this case, Tobin's $q$, the ratio of market value to replacement cost, would fall to zero.

Consider the response to a second unanticipated but permanent inward shift in demand to $D_{2}$. Assume that, prior to the disturbance, the

19. Note that the greater $\beta$ is, the less the price will fall for any shift in $V$.

20. This is a sufficient condition to guarantee that no further investment will occur.

21. The elasticity of segment $D_{S}^{\prime} C$ will be equal to the elasticity of product demand, $\beta$, since unions obtain all revenues, and $S=1$ (see equation 8 ). 
Figure 1. End Game with Leontief Production Technology

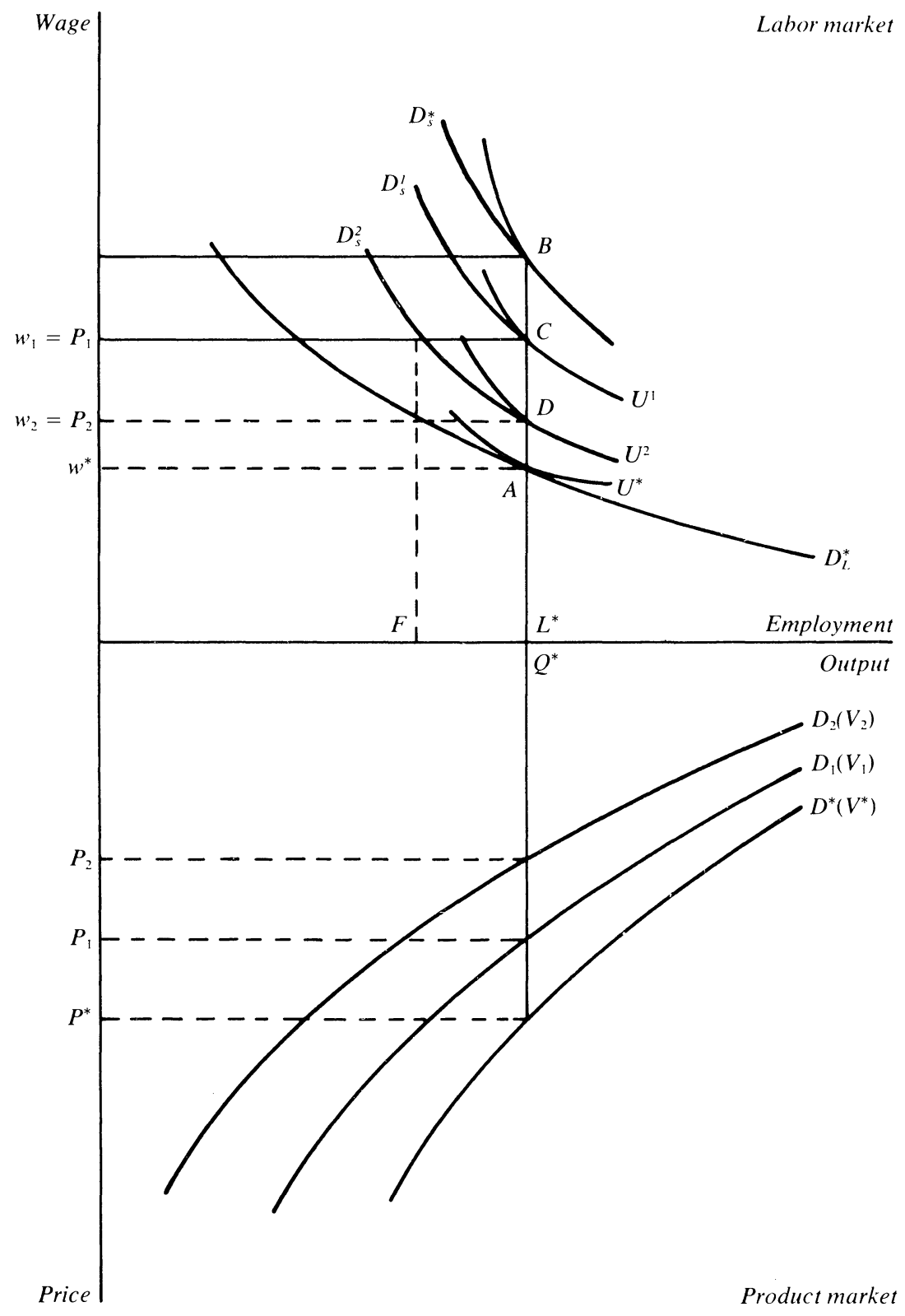


union had chosen wage rate $w_{1}$. Now the new kinked demand curve facing the union will be $D_{S}^{2} D L^{*}$. The union could choose a point like $D$, reducing wages to $w_{2}$ without a loss of employment. The price would decline to $P_{2}$. If the union maintained wages at $w_{1}$, it would lose $F L^{*}$ jobs as plants closed down. In general, depending on the degree of union risk aversion and the elasticity of product demand, the end of the end game could involve wage reductions accompanied by the possibility of shutdowns and layoffs.

More generally, when some elasticity of substitution between capital and labor is possible ex post, union wage demands are likely to be bounded by the shutdown point. Once that point is reached, and plants are being closed or threatened with closure, labor demand becomes more elastic, and wage rates are reduced.

Thus the response of union wages to a sequence of demand declines could well go through two distinct phases. In the first, the beginning of the end game, declining elasticity of derived demand induces higher wages and is associated with a drop in Tobin's $q$; in the second, the end of the end game, declining revenue (and the prospect of plant closures, which again raise the labor demand elasticity) induces wage reductions. Ceteris paribus, the more lumpy and long-lived the original capital is, the more dramatic the "scooping" of profit in the first phase is likely to be.

End Game with Ex Post Substitution. We now investigate the end game theory with a more general specification. We assume that the permanent decline in demand leaves the long-run capital stock $K^{*}$ unchanged. Firms may, however, still vary employment levels according to the production function, equation $3 .^{22}$ The new derived demand for labor for a fixed level of capital $K^{*}$ is

$$
\begin{aligned}
\log w=A & +\beta^{-1} V+\frac{\beta-\sigma}{\rho \sigma \beta} \log \left[\alpha L^{\rho}+(1-\alpha) K^{* \rho}\right]^{1 / \rho} \\
& +(\rho-1) \log L .
\end{aligned}
$$

The equilibrium condition is found by maximizing the expected utility

22. $K^{*}$ remains fixed, since, given a CES production function, no matter how high the wage, some level of employment is still marginally profitable, with the value of the marginal product covering at least the wage. If all firms are equally efficient, there will be no shutdowns as long as $\sigma \neq 0$. 
function 2 subject to equation 10 . It is given by equation 9 . The new elasticity of derived demand facing the union is

$$
\eta^{s}=\frac{\beta \sigma\left[\alpha L^{\rho}+(1-\alpha) K^{* \rho}\right]}{\alpha \sigma L^{\rho}+\beta(1-\alpha) K^{* \rho}} \geq 0
$$

The change in elasticities owing to the decline in product demand with industry-specific capital can be found by subtracting the long-run elasticity $\eta^{L}$ from $\eta^{S}$. Evaluating the change at the initial capital-labor ratio, this is

$$
\Delta \eta=-\frac{S^{*}\left(1-S^{*}\right)(\beta-\sigma)^{2}}{S^{*} \sigma^{*}+\beta\left(1-S^{*}\right)}<0,
$$

where $S^{*}$ is the share of labor evaluated at $w^{*} / r^{*}$. Equation 12 demonstrates that the derived demand elasticity for labor shrinks due to the reduced possibility of substitution between capital and labor. Except in the case of corner solutions, there is no monotonic relationship between $\beta, \sigma$, and $\Delta \eta$. The intuitive reason is that increases in the ratio of the wage to the rental price of capital induce both substitution and contraction effects. As long as $\sigma>\beta$, the lower $\sigma$ is, the more inelastic the derived demand curve will be.

Equilibrium, described in figure 2, is initially at point $A$. The subsequent shift in wages can be decomposed into two stages. The first, the elasticity effect, would occur in response to all types of disturbances that fix the capital stock. Since the actual capital stock is fixed, the new demand curve is less elastic (equation 12) evaluated at the previous equilibrium. Purely as a result of this effect, therefore, the union wage would shift from $A$ to $B$ along the new demand curve $D^{\prime} A B$, and wages would change by $w^{\prime}-w^{*}$. The second, the demand effect, is the inward shift in the less elastic derived demand curve resulting from the fall in demand per se. The demand curve $D^{\prime}\left(V^{*}, r^{*}, K^{*}\right)$ shifts to $D^{\prime \prime}\left(V_{1}, r^{*}, K^{*}\right)$ for $V^{*}>V_{1}$. The equilibrium shifts from $B$ to a point like $C$. This shift in wages is $w^{\prime}-w^{\prime \prime}$.

Overall wages will rise in end game if the elasticity effect dominates the demand contraction effect. When the elasticity of substitution is unity, the Cobb-Douglas case, the labor demand elasticity is not affected by shifts resulting from demand contraction. In this case, therefore, 
Figure 2. End Game with Ex Post Substitution Possibilities ${ }^{\mathrm{a}}$

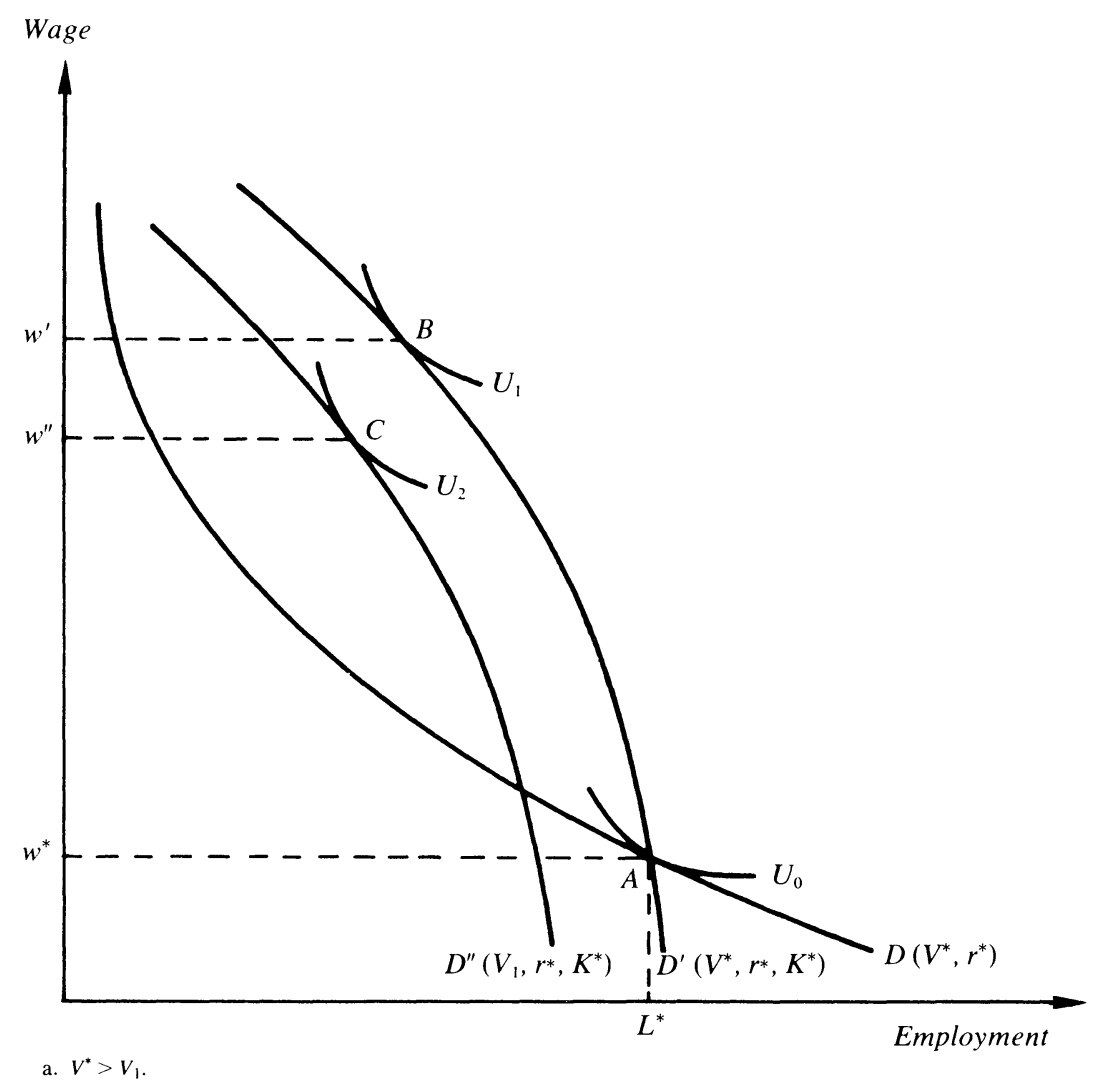

wages will rise unambiguously, since labor demand elasticity is only subject to the elasticity effect.

Analytically, the shift from point $A$ to point $C$ is found by differentiating the optimum condition, equation 9 , and using equations 10,11 , and 12 , which yields:

$$
\frac{d \log w}{d V}=\frac{S^{*}\left(1-S^{*}\right)(\beta-\sigma)^{2}+L f^{\prime}(L)}{\sigma \beta\left[\eta^{L}+R-1-L f^{\prime}(L)\right]},
$$

where $f^{\prime}(L) \equiv \frac{\partial \eta^{s}}{\partial L}$, and $R=-\frac{U^{\prime \prime}(w) w}{U^{\prime}(w)}$, or union relative risk aversion. 
Second order conditions imply that $R+\eta^{L}>1$ and $f^{\prime}(L)<0$, so that the denominator in equation 13 is positive. ${ }^{23}$ The first term of the numerator, the elasticity effect, is always positive, and the second, the contraction effect, is negative or zero. Except for the special cases where $\sigma=0$ and $\beta=0$, the sign of equation 13 is ambiguous. ${ }^{24}$

How do the initial factor shares affect the change in wages? We differentiate equation 11 with respect to the share of capital for a given wage-rental ratio and obtain

$$
\frac{\partial \eta^{s}}{\partial\left(\frac{1-\alpha}{\alpha}\right)}=\frac{\beta \sigma(1-S) S(\sigma-\beta)}{[S \sigma+\beta(1-S)]^{2}} .
$$

The change in $\eta^{s}$ and hence wages will depend on the size of $\beta$ relative to $\sigma$. If $\beta>\sigma$, then for any given initial wage-rental ratio, the higher the share of capital, the larger the wage increases in end game. When $\beta$ is high in end game, union power in capital-intensive plants will increase. Although the increase in price caused by higher union wages leads to a sharp reduction in revenues for high $\beta$, it is capital that bears the brunt of this revenue loss. Moreover, for low $\sigma$, the capital-intensive plant cannot easily increase the capital-labor ratio. Thus labor secures higher wages without significant loss in employment. If the decline in international competitiveness is associated with a rise in $\beta$ due to the introduction of new products, capital-intensive plants with lumpiness and little possibility of substitution between capital and labor will experience greater wage increases in end game.

\section{THE SLOW GAME}

The end game scenario analyzed above is a special case of slower demand growth. In this section, we set the model in a growth context to

23. The second order condition is explicitly derived in Colin Lawrence and Robert $Z$. Lawrence, "The Determination of Wages in Declining Industries: An Endgame and Slowgame Interpretation," First Boston Working Paper Series, FB-85-10 (Columbia University, 1985). If $R>1$, then the condition is necessary but not sufficient. If $R<1$, the condition is sufficient. Figure 2 is drawn for $f^{\prime}(L)<0$.

24. A Cobb-Douglas technology implies that $f^{\prime}(L)=0$ so that wages will unequivocally rise by $\frac{S^{*}\left(1-S^{*}\right)(\beta-1)^{2}}{\beta\left(\eta^{L}+R-1\right)} d V$ in this case. 
illustrate the more general wage response to declines in demand growth. We call this scenario the slow game. An extremely simple model illustrates our argument. ${ }^{25}$

Again we emphasize the difference between ex post and ex ante substitution possibilities. If ex post substitution possibilities are limited, and capital is long-lived, unions making wage demands have to be concerned primarily about capital-labor substitution in new investment. The higher the share of new capacity in production, the more elastic the derived demand for labor. Thus capacity growth and the elasticity of demand for labor are likely to be positively related. An exogenous decline in capacity expansion could, therefore, induce a higher union wage. We assume that ex ante the production technology is a puttyputty CES function. Ex post, however, capital must be used with labor in fixed proportions. We also assume that capital does not depreciate. ${ }^{26}$

At any time the production opportunity set facing the firm is nonhomothetic. Production involves the use of existing capital in a fixed proportion to labor and of new capital in a variable proportion to labor. Along a given steady-state path, with no improvements in productivity, capital and labor would grow at the same rate given the wage-rental ratio. The fact that ex post proportions are fixed implies that unions in existing plants could raise their wages up to a point without losing employment. However, by so doing they affect future employment opportunities for new members, since firms could respond by using more capital-intensive production methods.

We use subscripts with zero to indicate existing capital and labor, $K_{0}$ and $L_{0}$, and the output, $Y_{0}$, that it produces. We use $K, L$, and $Y$ to designate new capital, employment, and output, respectively. The ex ante production technology is described in equation 3. The firm's first order conditions for new plants are described by equations 4 and 5 . Output in existing plants is fixed at $Y_{0}$, as are the production coefficients. ${ }^{27}$

25. A complete dynamic model would of course incorporate heterogeneity of the union membership, rates of time preference, and differences in specific and general human capital.

26. In the presence of depreciation, unions have to be concerned about substitution as a result of gross investment. But depreciation does not change the qualitative nature of the results.

27. It is relatively simple to allow for the possibility of some substitution between capital and labor, as well as to incorporate endogenous utilization of capital services in lumpy plants. 
In any period, aggregate output, $\bar{Y}$, is produced with old and new capital and labor; thus

$$
\bar{Y}=Y_{0}+Y ; \bar{L}=L_{0}+L ; \bar{K}=K_{0}+K .
$$

The demand curve facing the industry is:

$$
\log Y^{d}-\log Y_{0}=g-\beta\left(\log P-\log P_{0}\right) .
$$

In the steady state, capital, labor, and output would all grow at $g$, while $P$ and $w / r$ would remain constant.

The aggregate derived demand for labor during the decision period can be found by using equations 14 and 15 and the first order conditions 4 and 5:

$$
\bar{L}^{d}=L_{0}+S\left(Y_{0}+Y\right)^{-1 / \beta} e^{(1 / \beta) g} Y w^{-1} Y_{0}^{1 / \beta} P_{0},
$$

where $S$ is the share of labor defined in equation 8 . The unions choose $L$ and $w$ to maximize $\bar{L}(U(w)-\bar{U})$ subject to equation 16 . The first order equilibrium condition is described by

$$
\frac{U^{\prime}(w) w}{U(w)-\bar{U}}=S \beta+V(1-S)_{\sigma},
$$

where $V=g\left(Y_{0} / \bar{Y}\right) \equiv(Y / \bar{Y})$. The right-hand side of equation 17 denotes the derived demand elasticity. It depends on the share of output produced by new plants, $V$, and the long-run Hicksian elasticity, $\eta^{L}$. If all output is produced by new investment $(V=1)$, then the aggregate elasticity is the Hicksian elasticity $\left[\eta^{L}=S \beta+(1-S) \sigma\right]$. On the other hand, in end game, there is no new investment $(V=0)$, and the elasticity will be $S \beta$. Figure 3 traces out this relationship. At point $A$, all output is produced by new plants, while at point $B$ an end game situation has occurred. Figure 4 shows how different values of $V$ would affect the derived demand for labor schedules. As $V$ rises, the entire schedule shifts to the right, and the elasticity increases, since a greater share of plants will now have an ex ante elasticity of substitution equal to $\sigma$. In the end game situation, the elasticity will decline to $S \beta .{ }^{28}$

28. Note that there is a range of wage increases in which the unions can extract some profits without any plant shutdowns. See figure 1 for a full explanation of this phenomenon. 
Figure 3. Derived Demand Elasticity with Economic Growth ${ }^{a}$

Derived demand

elasticity $\left(\eta^{L}\right)$

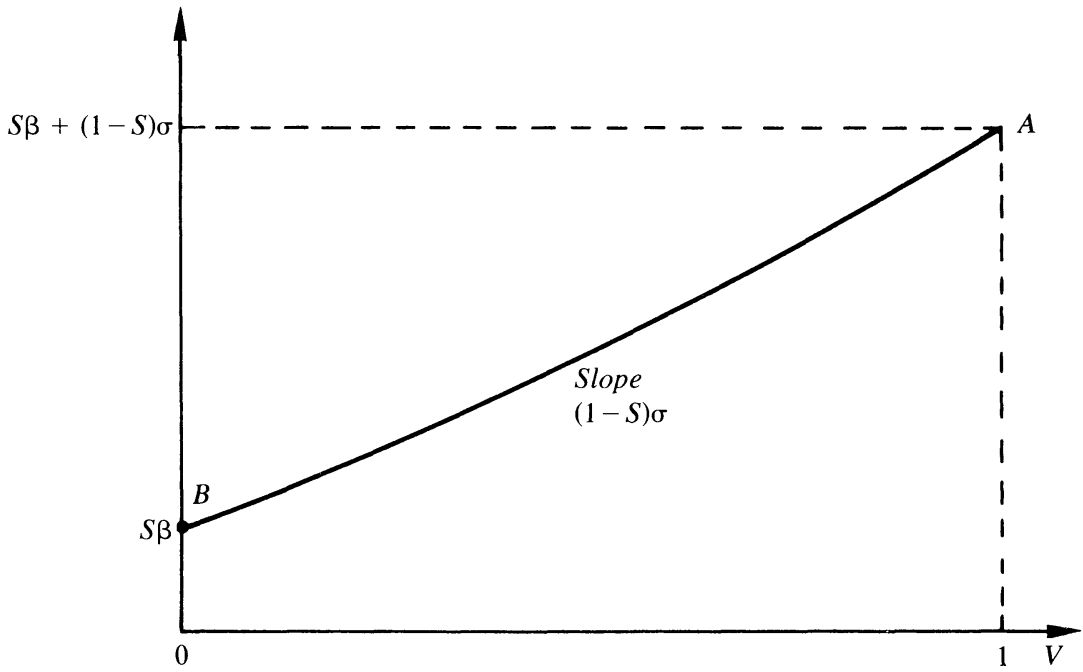

a. Note that along the path $B A$, the wage-rental ratio is being held constant.

Wage Determination under Slow Game. Consider an economy with the demand for $Y$ growing at $V^{*}$, with $V^{*}$ equal to the proportion of new plants each period, as depicted in figure 5. Equilibrium is at point $E$. If $V^{*}$ falls to $V_{1}$, the derived demand schedule will shift inward to $D\left(V_{1}\right)$. $D\left(V_{1}\right)$ will be less elastic than $D\left(V^{*}\right)$. Any increase in wages will lead to a smaller reduction in employment growth in comparison with the higher growth scenario. What wage will the union choose? There is a substitution effect and a contraction effect. The substitution effect alone would lead unions to push wages up to $w^{S}$ (equilibrium is at point $F$ ), whereas the contraction effect alone would reduce both wage and employment growth. In figure 5, the combined impact of the two effects is at point $G$, where wages have risen from $w^{*}$ to $w^{U}$. Of course, the contraction effect could dominate the substitution effect, and wages could fall below $w^{*}$. To establish what happens to wages in the new steady state, we fully differentiate the equilibrium condition (equation 9) and the labor demand 
Figure 4. Derived Demand Labor Schedules with Growtha

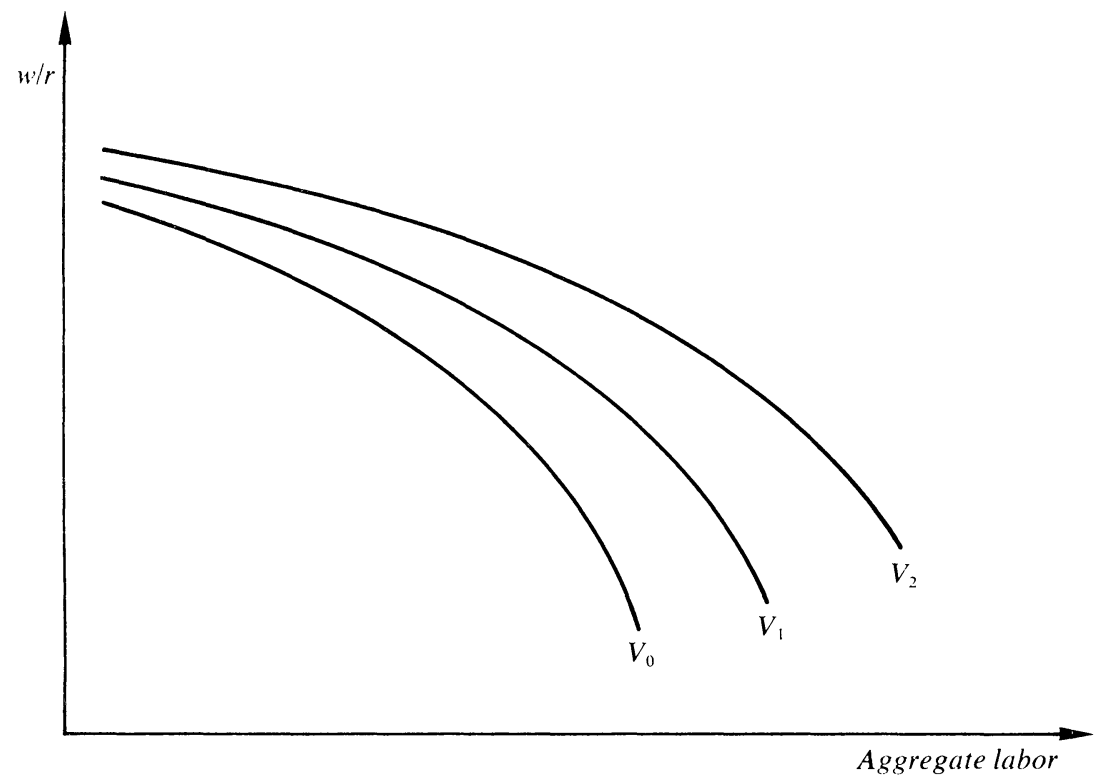

a. $V_{2}>V_{1}>V_{0}$.

schedule (equation 16). Under the assumption that $\sigma=1$ (the CobbDouglas case), the solution is

$$
\begin{gathered}
\frac{d \log w}{d V}=\frac{-(1-S)}{\eta^{L}\left(\eta^{L}+R-1\right)}<0, \\
\frac{d \log \bar{L}}{d V}=\frac{(1-S)}{\left(\eta^{L}+R-1\right)}+1>0 .
\end{gathered}
$$

As long as the sufficient condition for equilibrium holds $\left[\left(\eta^{L}+R\right)>1\right]$, then a slowdown in growth will unambiguously lead to higher wages and lower employment growth. Thus, ex ante putty-putty Cobb-Douglas technology and McDonald-Solow union preferences guarantee that the elasticity effect dominates the contraction effect. In other circumstances, the solution is ambiguous.

The reader should be aware how similar slow game is to end game in terms of union wage bargaining. However, slow game has the appeal of symmetry. In the presence of unions, wages could fall in an industry that experiences an expansion in demand for its product. 
Figure 5. The Slow Game Scenario and Wage Determination

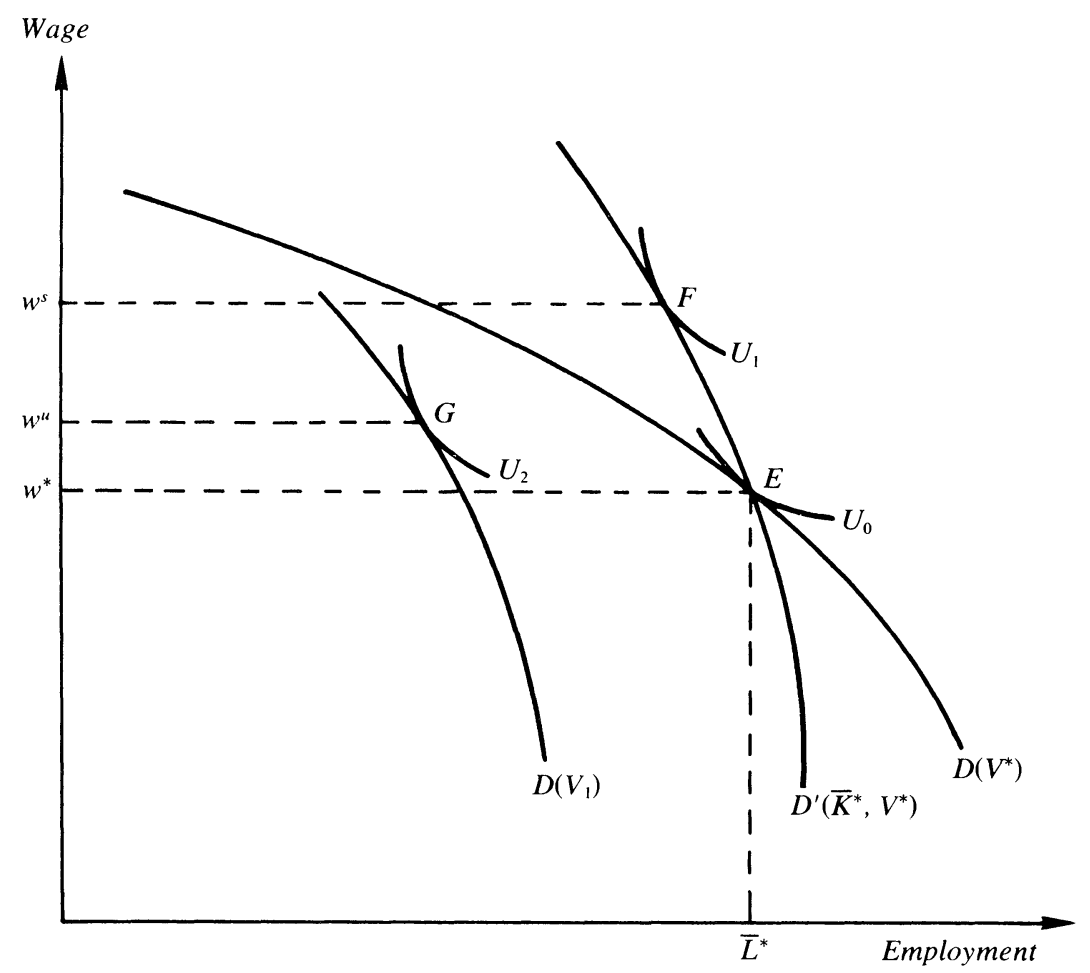

QUALIFICATIONS AND EXTENSIONS

We have demonstrated that an end game can result from a decline in international competitiveness. Similar effects could result from other shocks, in particular, a rise in the cost of capital (or a complementary factor such as energy), or a decline in capital productivity (perhaps due to regulatory or environmental requirements, or to a shift in relative prices that requires experimentation with new technologies). Elsewhere, we have demonstrated that an exogenous decline in the productivity of capital will lead to more inelastic derived demand for labor, providing that $\sigma>\beta .{ }^{29}$ That decline could also induce precisely the end game or

29. See Lawrence and Lawrence, "The Determination of Wages." In the event that $\beta$ $>\sigma$, but $\sigma<\beta \delta$, where $\delta$, bounded between 0 and 1 , measures the decline in productivity, the derived demand will become more inelastic. 
slow game results described here. Since, if $\sigma>\beta$, the decline in the productivity of capital induces an outward shift in the derived demand for labor that reinforces the elasticity effect, regardless of union preferences, wages will rise in response to the shock..$^{30}$

Heterogeneous Workers. In the model the assumption was that all workers had an equal chance of employment. In the real world, workers are typically hired and fired according to seniority rules, and they face different probabilities of layoff. ${ }^{31}$ In addition, depending on their industry-specific human capital, workers may face different opportunity costs if displaced. Preferences, age, and seniority could be systematically related. ${ }^{32}$ By changing union membership, growth could alter the age and seniority of the median union voter as well as the elasticity of labor demand.

Positive Investment. The end game scenario above suggested zero investment in the face of an inward shift in the demand curve. In reality, investment may continue in many end game situations. Firms are, after all, heterogeneous. Some may adopt strategies to survive and expand even though aggregate production stagnates. The nature of capital investment is varied as well. A firm that does not wish to expand capacity may still need to invest in maintenance. Indeed, a shock that makes investment in one type of capital impossible may raise the demand for other types of capital (but still lower the elasticity of demand for labor). In a three-input homothetic production function with immobile capital, mobile capital, and labor, an end game situation will lead to positive mobile capital investment if the substitution effect dominates the contraction effect. In the Cobb-Douglas cases, positive investment will be observed if $\beta<S(1-S) .{ }^{33}$

30. To ascertain the impact on the change in $\eta$, differentiate equation 12 with respect to $\delta \equiv \% \Delta[(1-\alpha) / \alpha]$ at the initial $w^{*} / r^{*}$ ratio and obtain

$$
\frac{\partial \Delta \eta}{\partial \delta} \mid \frac{w^{*}}{r^{*}}=\frac{S^{*}\left(1-S^{*}\right)(\sigma-\beta \delta)(\sigma-\beta)}{S \sigma+\beta \delta\left(1-S^{*}\right)} .
$$

Evaluate this for values of $\sigma, \beta$, or $\delta$ and obtain the results in the text.

31. For an analysis of union response to a decrease in international competitiveness using a model in which union membership is determined endogenously, see Gene M. Grossman, "International Competition and the Unionized Sector," Discussion Papers in Economics, no. 29 (Woodrow Wilson School, Princeton, New Jersey, May 1982).

32. See Gregg Easterbrook, "Voting for Unemployment,"' The Atlantic, vol. 251 (May 1983), pp. 31-44.

33. A proof of this can be found in Lawrence and Lawrence, "The Determination of Wages," appendix 2. 
Finally, in the real world, disturbances are rarely clearly labeled as permanent or temporary. Uncertainty may induce firms to continue investment but at a slower pace, while workers raise their wage demands but do not scoop profits entirely.

Our very simple model grants workers monopoly power while firms are perfectly competitive. But the end game theory does not rest on the assumption of asymmetric information. Both management and labor perceive accurately that once new investment is no longer viable, the power of management erodes because it can no longer threaten to use less labor-intensive production methods or not to build new plants.

In more complex real-world cases of bilateral monopolies or oligopolies, shifts that lower the demand elasticity for labor should raise labor's bargaining power, but the analysis would necessarily have to be different. ${ }^{34}$ In particular, a management with high profits may be able to withstand a strike and thus exact concessions. On the other hand, a management in a precarious position may be able to do likewise. More detailed examination of the behavior of owners and management under economic conditions such as those prevailing in the 1970s may yield further insights into the wage determination process. ${ }^{35}$

Work Rules. In the model just considered, the union's utility function was specified purely in terms of employment and wages. However, instead of seeking higher wages, the union might seek to improve working conditions even at the cost of lower productivity. Thus working conditions would enter the utility function positively and the production function negatively. In this case, it is straightforward to show that a decline in the demand elasticity as a result of end game will result in demands for altered work rules in addition to higher wages. Declining worker productivity may well be a concomitant of end game.

\section{Testing the End Game: The U.S. Steel Industry, 1970-84}

Relative steel wages in the United States over the past fifteen years have conformed closely to the forecast of the end game theory: in the

34. See McDonald and Solow, "Wage Bargaining and Employment."

35. In the presence of (physical) depreciation the analysis becomes more complex, since it clearly has a much stronger intertemporal aspect. With fixed coefficients ex post, in the end game, as plants wear out, employment declines. Nonetheless, since by assumption new investment is not profitable even at the opportunity wage, the union gains nothing by lowering its wages. 
1970 s, a period of stagnant demand and investment, relative average hourly wages increased by 27 percent; between 1982 and 1984, in response to deep declines in demand and plant closures, they declined by 12 percent.

Several characteristics of the U.S. steel industry make it a prime candidate for an end game interpretation of its wage behavior. First, most workers in the traditional integrated steel industry belong to the United Steelworkers Trade Union. Second, exit barriers are substantial: steel is produced in large plants that are highly capital-intensive and long-lived. And, third, during the 1970s, the prospects for the industry deteriorated markedly but not sufficiently to induce major plant closures or employment declines.

The industry's problems since 1970 stem from a combination of demand and supply-side factors. The ratio of steel consumption to GNP has gradually declined in mature industrial economies as they have passed through the phase of building steel-intensive infrastructure such as ports, bridges, power plants, railroads, and highways. ${ }^{36}$ There has also been a secular trend toward the substitution of alternative materials such as aluminum and plastic for steel. During the 1970 s, slow worldwide economic growth, which reduced investment in heavy industry, and high energy prices, which accelerated the substitution of lighter alternative materials, reinforced the trend toward declining steel use. Despite the 36 percent increase in U.S. GNP between 1970 and 1980, steel consumption in the United States actually decreased by 2 percent.

The large integrated U.S. steel producers were unsuccessful even in maintaining their share of this shrinking market. In 1960, foreign producers and U.S. mini-mills produced 5 percent of the steel consumed in the United States; by late 1982, their share of the U.S. market had grown to almost 40 percent. ${ }^{37}$ By the early 1970 s, the technological superiority enjoyed by big U.S. steelmakers, especially during the 1950s, had eroded. Worldwide declining transportation costs and falling real iron ore prices had also reversed the longstanding U.S. advantage in raw materials. Even if U.S. steel wages had been at Japanese levels, Japanese steel would have been cheaper. ${ }^{38}$ It became increasingly obvious that the

36. See Donald F. Barnett and Louis Schorsch, Steel: Upheaval in a Basic Industry (Ballinger, 1983).

37. Ibid., p. 79.

38. See the estimates of manhours per ton in Barnett and Schorsch, Steel, p. 123. 
construction of new integrated steel facilities in the United States was not a viable proposition. It was cheaper either to build such plants in newly industrializing countries or to build mini-mills in the United States. These judgments were shared by expert analysts, participants in the stock market, and, as revealed by their behavior (if not their statements), steel management.

According to Donald F. Barnett and Louis Schorsch, for example, "No reasonable set of assumptions can be selected to generate an attractive rate of return on investment for new integrated plants. . . . Even with state-of-the-art techniques, labor requirements in integrated facilities are roughly twice those of mini-mill operations. . . . Massive modernization in its purest form-the construction of greenfield plants of the minimum efficient scale-would not improve their competitiveness against their principal foreign competitors. . . . The financing costs [of building such a plant would] swamp the efficiency benefits." 39 Robert W. Crandall concurred with this view, "Given the labor-intensity in the production of steel and in the construction of steelmaking facilities, the United States is not in a favorable position to expand steel capacity through the construction of new integrated works." 40

The stock market's appraisal matched that of these experts: Tobin's $q$, the ratio of market value to replacement costs, for the steel industry had been less than unity as early as 1960 ; by $1970, q$ for steel had fallen to 0.3 (see table 1), and throughout the decade it languished at or below that level. Steel investment patterns also matched these perceptions. The U.S. industry had expanded capacity during the 1950s from 90 to 136 million tons and had engaged in considerable modernization and capital-deepening during the 1960s; but during the 1970s, investment was devoted primarily to the maintenance of existing plants. ${ }^{41}$ In 1980 the industry had the same capacity that it had in 1970, while between 1970 and 1980, as officially measured, its gross capital stock declined 3 percent. The actual rate of disinvestment is probably understated, since the official capital stock data include both government-mandated expenditures, which do not increase capacity, and nonsteel investments,

39. Ibid., pp. 179-80.

40. Robert W. Crandall, The U.S. Steel Industry in Recurrent Crisis: Policy Options in a Competitive World (Brookings Institution, 1981), p. 91.

41. See William T. Hogan, World Steel in the 1980s: A Case of Survival (D.C. Heath, Lexington Books, 1983), p. 92; and Barnett and Schorsch, Steel, p. 148. 


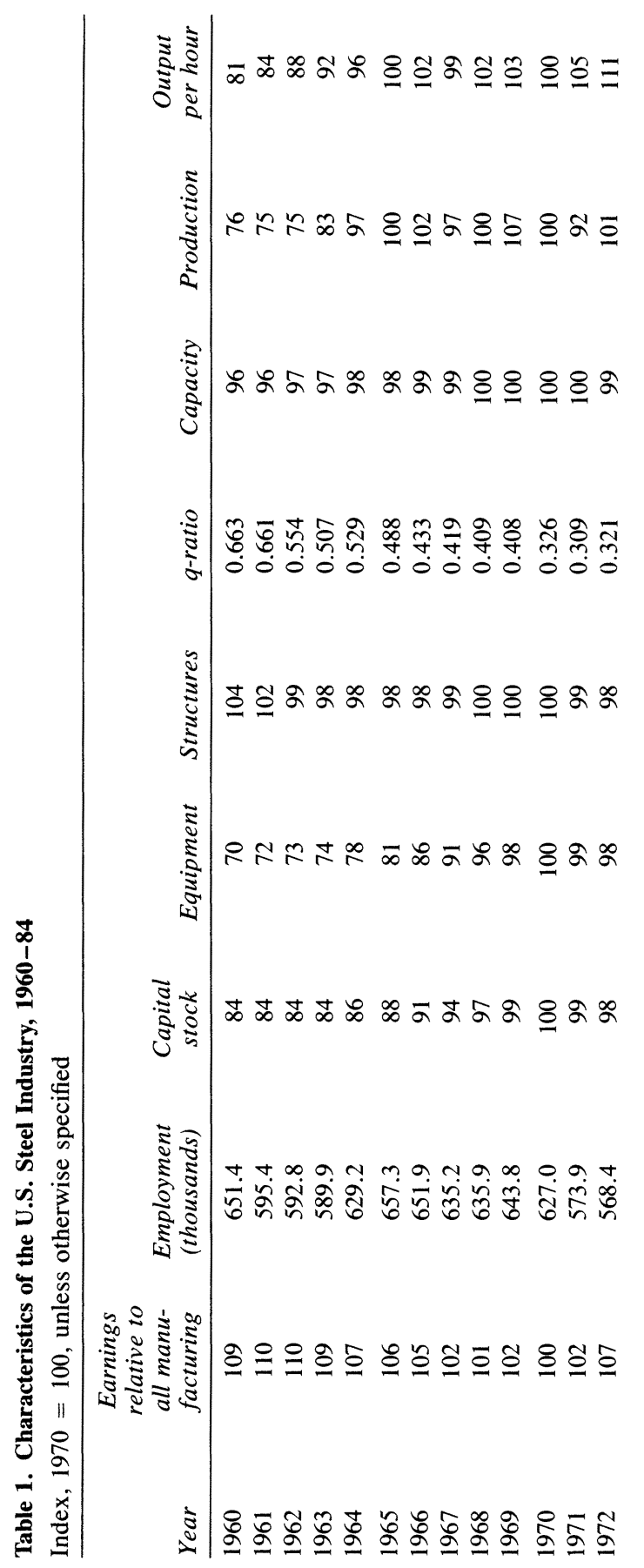




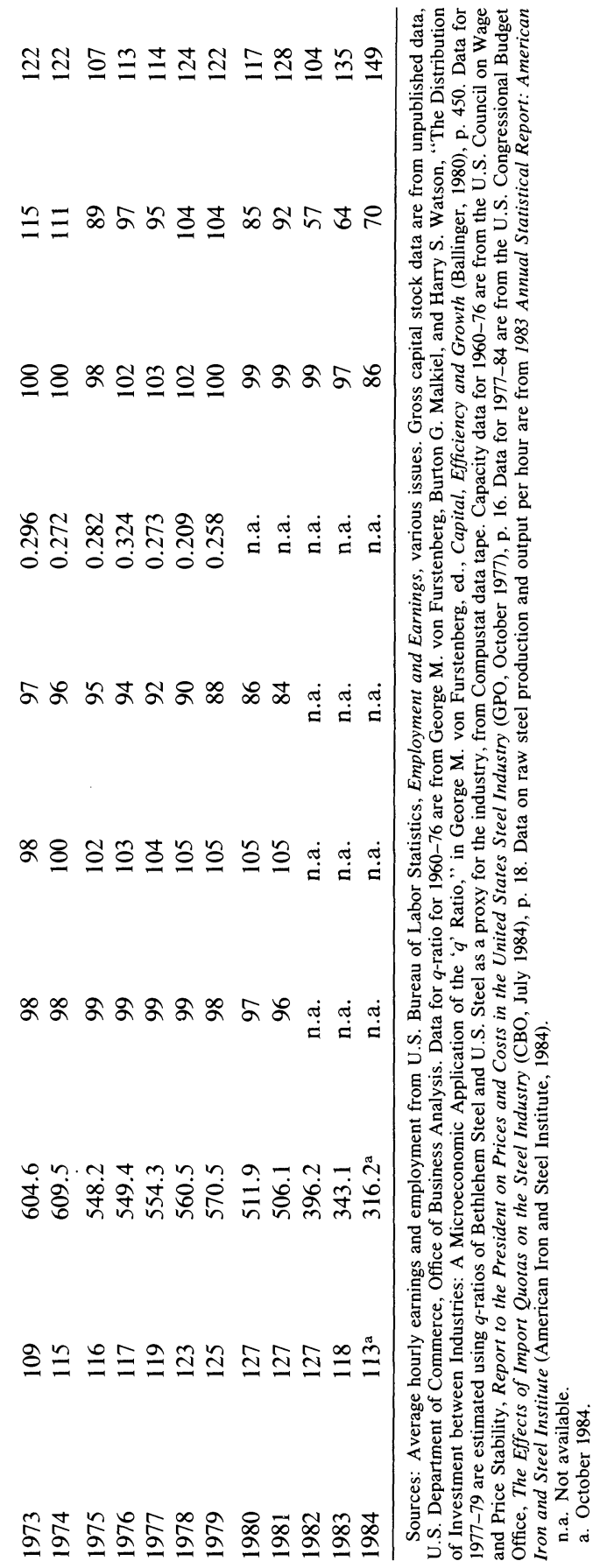


which have been increasing in recent years and constituted roughly 30 percent of investment by steel firms in $1980 .{ }^{42}$

Still, although new investment in steel had become unprofitable, variable costs could usually be covered, and economic considerations still justified operating existing plants. In addition, management was uncertain about the future path of steel demand and tried to keep existing plants operating with a view to meeting shortages in the event of a resurgence in demand. In his 1981 study, Crandall concluded that existing capacity would remain relatively intact. He argued, "The best existing U.S. mills have operating and incremental capital costs that are very close to the costs of operating and amortizing the capital investment of new mills in eastern Asia. Therefore, while new mills are not likely to be built in the United States in the foreseeable future, at current exchange rates the most efficient U.S. mills should have little difficulty defending their home markets from major increases in import penetration from even the most efficient exporting countries." 43 And he predicted, "The U.S. steel industry will lose capacity gradually over the next decade [the 1980s] but this loss will be no more than 10 percent even without trade protection.", 44

Over the 1970s, therefore, circumstances in the steel industry conformed to those of phase one of the end game. Shocks had radically reduced desired investment but had not led to substantial reductions in capacity or employment. As indicated in table 1, capacity peaked in 1977, when it was only about 3 percent above the 1970 level, and then declined gently until 1984, when there was a precipitous fall. Similarly, employment remained fairly stable, ranging from 549,000 to 627,000 jobs between 1970 and 1979.

The end game theory predicts that the following circumstances will accelerate union wage demands: substantial amounts of fixed plant with limited prospects for either growth or scrappage; workers unlikely to lose either potential or actual employment opportunities if their wages were increased; management without the credible threat of investing in new, more capital-intensive plants or of shutting down the old plants. The steel industry, as described, conforms exactly with the end game model. Its relative wages behaved as predicted.

42. Barnett and Schorsch, Steel, p. 146.

43. Crandall, The U.S. Steel Industry, p. 92.

44. Ibid., p. 153. 
Discussions with members of the steel industry during the 1970s would have elicited fierce denials that steel was actually in an end game. The conventional explanation for steel wage behavior is institutionalist. Management's fears of a strike and its impact on import penetration induced it to provide an extremely generous contract in 1974 in return for a no-strike pledge. In subsequent contracts, it is said, disputes over union leadership induced excessive wage demands. But it is preferable to examine the actual behavior of both the union and management rather than their rationalizations about their behavior. Certainly union members felt that there was little relationship between their wages and their jobs; they perceived that the derived demand curve for labor was highly inelastic. And management, apparently, was forced to accede to their wage demands.

Acquisition patterns in the 1970 s belie management denials that steel was in the end game. Declining capital-intensive industries become "cash cows." They generate cash flow but not new investment opportunities. Our end game theory describes union efforts to milk those cows. However, management may seek to milk the cows before the unions do. Because their large depreciation expenses had increased their cash flow, steel firms became the target of conglomerate acquisitions in the late 1960s. Several major companies were acquired by much smaller conglomerates-Jones and Laughlin by Ling-Temco-Vought, Youngstown by Lykes, and Sharon by NVF. Steel management responded in the early 1970s by beginning to diversify in earnest. By 1982, with its acquisition of Marathon Oil, U.S. Steel could more accurately be called U.S. Oil. ${ }^{45}$

Another alternative hypothesis blames the rising steel wage premium on trade protection. In principle, trade protection could explain why relative steel wages increased, since protection in the form of quotas may lower the product demand elasticity and thus the derived demand for labor. And in fact steel was subject to quota protection between 1969 and 1974 in the form of a voluntary restraint agreement with Japanese and European exporters that limited exports to the United States to a target of 14 million tons in 1969 and somewhat higher amounts in subsequent years. However, according to Crandall, "Most studies of

45. U.S. Steel began to diversify into chemicals in the late 1960s. Barnett and Schorsch, Steel, pp. 81-83. 
this program have found that it raised prices and limited imports through 1972 but was not binding thereafter." 46 Therefore, when the Experimental Negotiating Agreement (the novel no-strike agreement) was signed in 1974, U.S. steel enjoyed no formal or informal protection arrangements. The second bout of protection occurred with the 1978 implementation of the trigger price system, which placed a floor on prices at which imports could enter the U.S. market. At price levels below the trigger price, such a system makes the derived labor demand curve less elastic by eliminating foreign supply responses. Above the trigger price, it leaves supply unaffected. According to Crandall, in the absence of trigger prices U.S. steel prices would have averaged at most 2.7 percent less than those recorded in 1979. Thus the trigger price system is unlikely to have exerted a major influence on wages.

Japanese steel exports to the United States remained suspiciously close to 6 million tons each year between 1978 and 1981. Although never formally announced, it is likely that this reflected an implicit voluntary restraint agreement by the Japanese. Nonetheless, since most steel is fairly homogeneous, alternative sources of supplies make it unlikely that this protection materially affected the derived demand for union labor. In summary, protection may have facilitated, but is unlikely to have induced, the major rise in relative steel wages in the 1970s. It was too small, intermittent, and, in the case of the trigger prices, unlikely to have affected appreciably the demand elasticity for steel labor.

THE END OF THE END GAME

Beginning in 1980 several developments moved steel from the "scooping" phase of the end game, in which wages rise, to the end of the end game, in which they fall. The second energy shock accelerated the move to small cars and lighter materials. The subsequent decline in oil prices reduced the demand for oil-drilling equipment. Back-to-back recessions in 1980 and 1982 and the post-1980 rise in the U.S. dollar sharply cut steel employment and capacity. In 1984, despite two full years of economic recovery, U.S. steel employment was 38 percent below its 1981 level, and capacity had declined by about 14 percent.

In March 1983 the steel industry negotiated a wage contract that

46. Crandall, The U.S. Steel Industry, p. 103. 
marked a qualitative change from previous patterns and procedures. ${ }^{47}$ Its principal feature was an immediate 9 percent reduction in compensation, which was to be restored over the life of the contract.

Equally significant were numerous concessions occurring outside the traditional industrywide negotiations between the union and the coordinating committee dominated by U.S. Steel. Among other things, work rules were radically altered in local negotiations, while agreements at individual plants or companies provided more substantial reductions in compensation than those included in the general contract. (In 1982 such agreements were concluded at McLouth and Wheeling-Pittsburgh.) Wage reductions were also associated with changes in ownership. For example, when employees of National Steel's Weirton plant purchased that facility from the company, they agreed to a 30 percent reduction in wages.

\section{STEEL PRODUCTIVITY}

A corollary of the end game theory is that productivity growth and wage growth are likely to be negatively correlated. In the first phase of the steel end game, productivity growth stagnated as output per manhour remained virtually flat between 1973 and 1980. However, output per manhour in steel will generally be sensitive to the level of capacity utilization, and, as the following regression on annual data from 1960 to 1984 indicates, the flat productivity performance in steel after 1973 can be fully accounted for by lower capacity utilization levels:

$$
\begin{gathered}
\mathrm{OH}=3.74+0.015 T+0.56 U T+0.13 D 74-82+0.21 D 83+0.36 D 84, \\
\begin{array}{c}
(67.3) \\
(7.4) \quad(9.2) \quad(0.5)
\end{array} \\
\text { Standard error }=0.028 \quad \text { Durbin-Watson }=1.822
\end{gathered}
$$

where $O H$ is output per manhour expressed in logarithms; $T$ is time; $U T$ is the ratio of output to capacity (see table 1 ); $D 74-82$ is a dummy variable equal to unity between 1974 and $1982 ; D 83$ and $D 84$ are dummy variables equal to unity in 1983 and 1984, respectively; and the numbers in parentheses are $t$-statistics. ${ }^{48}$ The dummy for 1974-82 is insignificant, indicating that the productivity slowdown in steel can be accounted for

47. This account draws heavily on Barnett and Schorsch, Steel, pp. 70-71.

48. Corrected for first order serial correlation $(\mathrm{Rho}=0.27)$. 
by adjusting for capacity utilization. This suggests that the capacity data do not fail to account for premature scrapping as a result of the energy shocks. Steel does not support Martin Neil Baily's hypothesis that the productivity slowdown reflects a decline in capital services due to the accelerated economic obsolescence of capital..$^{49}$ Nor, in this phase, does it support our corollary hypothesis that, in the end game, unions may tighten work rules in addition to seeking higher wages.

In the second phase of the end game, however, despite much lower levels of capacity utilization, output per manhour in steel improved markedly. In 1983, with production about 30 percent lower than in 1981, output per manhour was actually 5.5 percent higher. The dummy variables for 1983 (D83) and 1984 (D84) indicate that output per manhour was 21 and 36 percent higher, respectively, than might have been expected. In part this could be due to the closure of the most inefficient plants and the growing share of production accounted for by new minimills. However, it could also reflect the relaxation in work rules that accompanied phase two of the end game in steel.

In summary, therefore, the steel industry is an ideal candidate for testing the end game. The industry endured a period of over a decade with bleak demand prospects but relatively few plant closures. Union wage behavior reflected the opportunities that these circumstances provided for obtaining higher wages. Many observers have suggested that the high U.S. steel wages explain the decline in the competitiveness of the U.S. steel industry. In our view, the reverse is more nearly true: the decline in competitiveness explains the rise in steel wages.

\section{Testing the Slow Game: Wages in U.S. Manufacturing, 1960-84}

From the 1960s to the 1970s the United States suffered a marked decline in the growth of demand for manufactured goods. Output growth in manufacturing dropped 16 percent from the 1960s to the 1970s. The slump did not reflect different cyclical conditions at the end of each

49. Martin Neil Baily, "Productivity and the Services of Capital and Labor," BPEA, 1:1981, pp. 1-50, and "The Productivity Growth Slowdown by Industry," BPEA, 2:1982, pp. 423-54. 
decade. Capacity utilization in manufacturing, as measured by the index of the Federal Reserve Board, was 80.2 percent in 1960, 79.5 percent in 1970, and 79.6 percent in $1980 .{ }^{50}$ Nor was it the result of a shift in the historic relationship between overall growth and manufacturing output. Rather, it was the predictable result of the decline in GNP growth itself. ${ }^{51}$ GNP grew more slowly because of a (poorly understood) decline in productivity and because of increased cyclical instability resulting from inflation and energy shocks. Manufacturing output behaved accordingly .

How should relative wages respond to this medium-term decline in the growth rate? The slow game theory suggests that if substitution effects dominate contraction effects as discussed above, they should rise in unionized industries with large amounts of specific fixed capital. In this section we test this conjecture with a sample of fifty-seven U.S. manufacturing industries. (The sample of industries, which accounted for 85 percent of manufacturing employment in 1980, is listed in table 2.)

Before considering the regressions, compare the ten industries in this group that have the highest wage growth with the rest of the sample. As can be seen in table 3, the ten industries conform to the slow game profile. On average, the capital-labor ratio in these industries in 1980 was twice as high as in the rest of manufacturing; 69 percent (19.3 percentage points) more of the work force worked in large plants; 34.6 percent (20.5 percentage points) more of the work force was unionized; and the four largest firms (measured by sales) accounted for 29.5 percent (11.2 percentage points) more output. With the exception of the unusually low proportion of female employees, in other respects these industries were similar to the rest of manufacturing in their demographic and regional characteristics.

The theory suggests that these industries will also have had relatively slower growth than average. And in fact they have, in both output and employment. In the 1970s, on average, their output increased 16 percent, compared with 27.4 percent for the typical industry in the sample; during the $1960 \mathrm{~s}$, the growth in output was 29 and 42.8 percent, respectively.

50. In 1984 , average capacity utilization was 81.6 percent.

51. Regressions of manufacturing output on GNP between 1960 and 1973 track manufacturing output, given GNP out of sample over the subsequent decade, extremely accurately. See Robert Z. Lawrence, Can America Compete? (Brookings, 1984). 


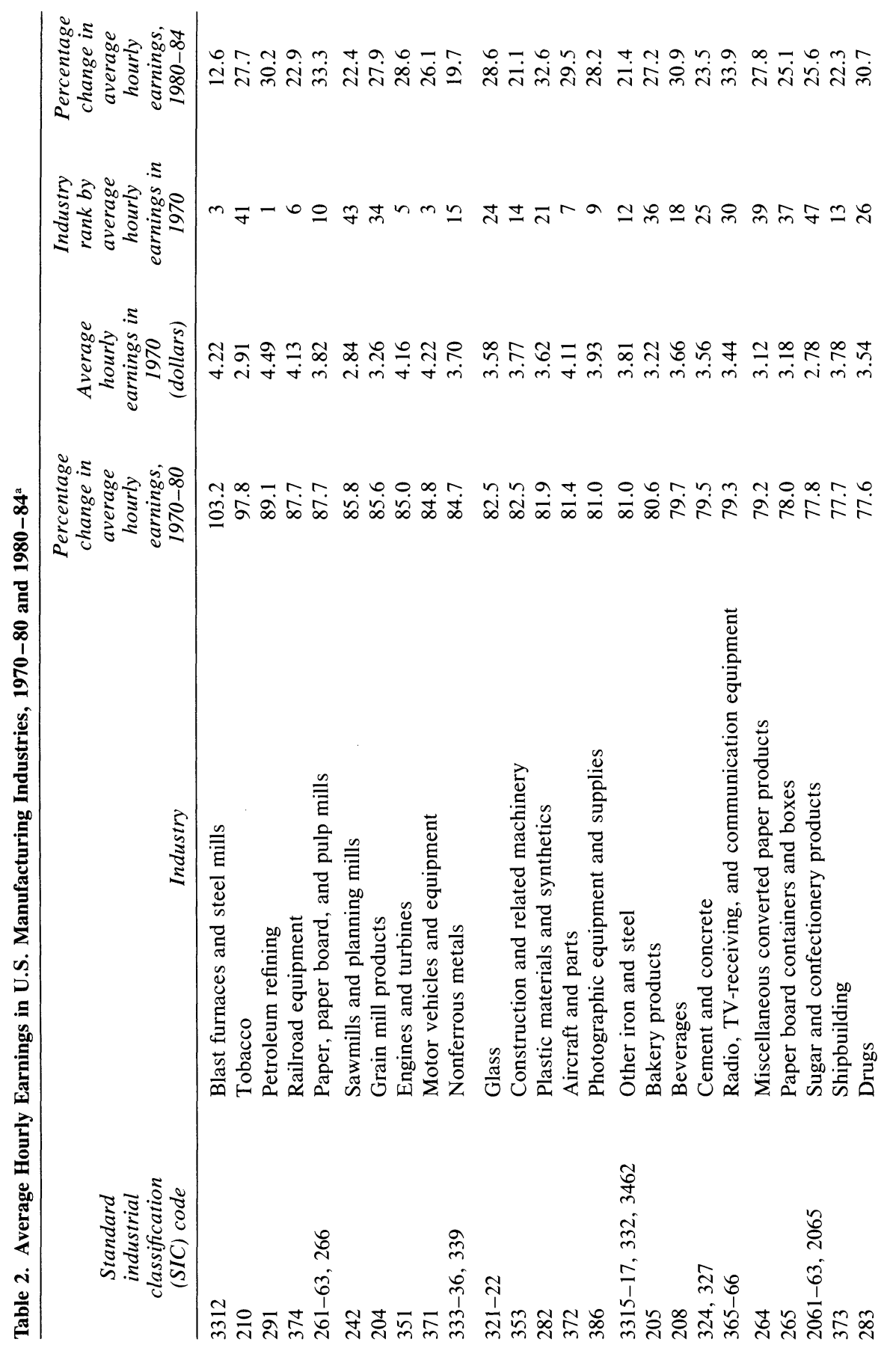




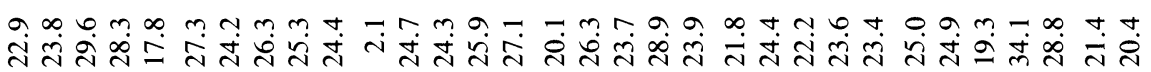

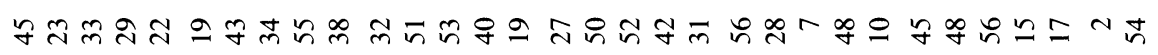

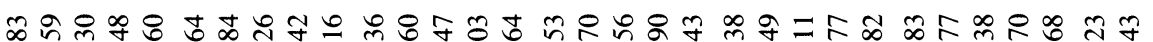

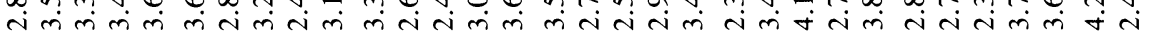

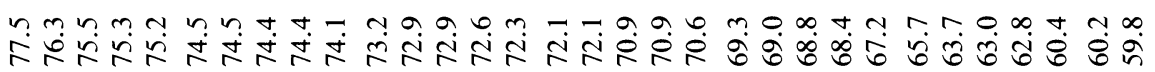

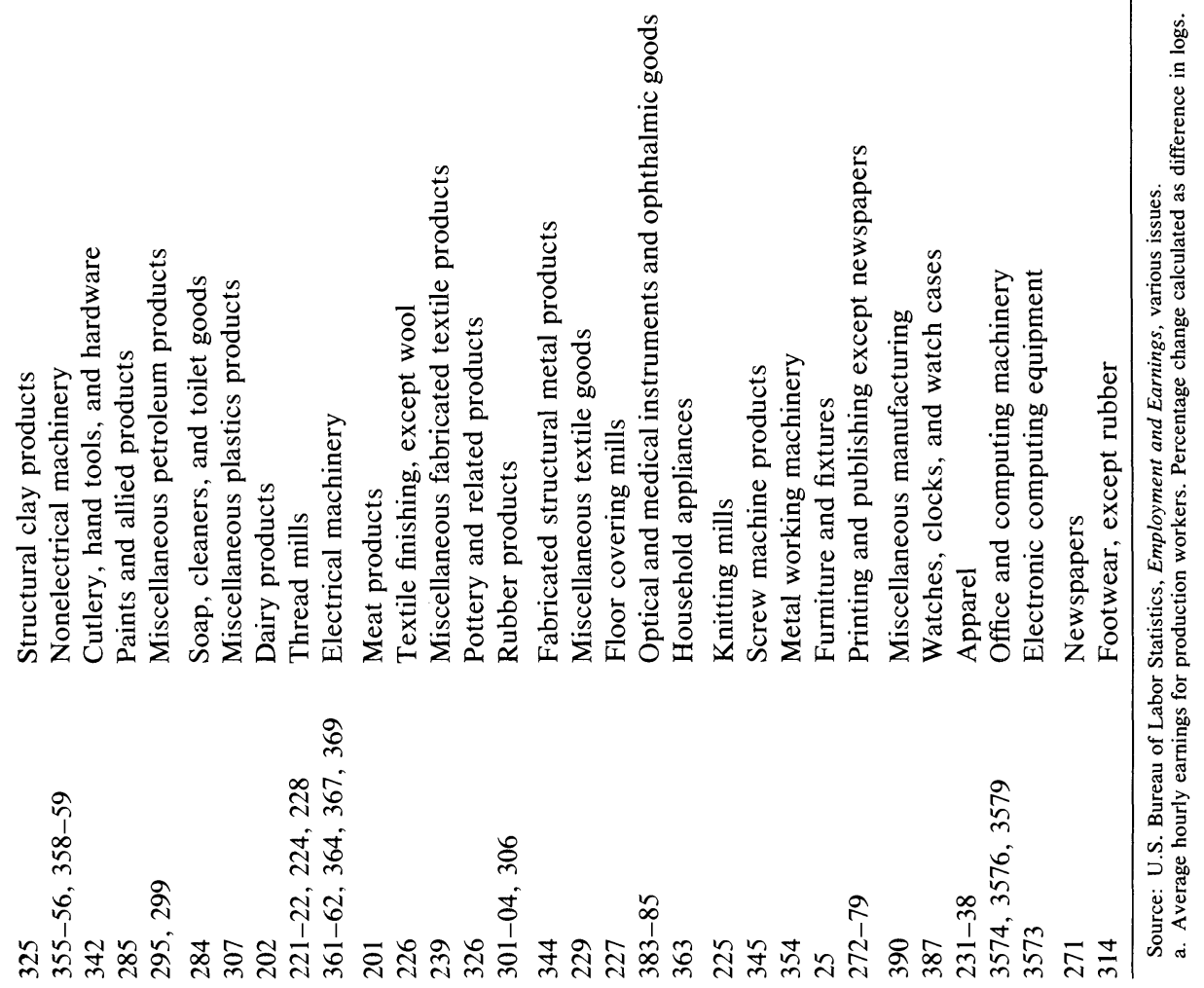


Table 3. Profile of U.S. Manufacturing Industries, $1960-80^{\mathrm{a}}$

Percent unless otherwise specified

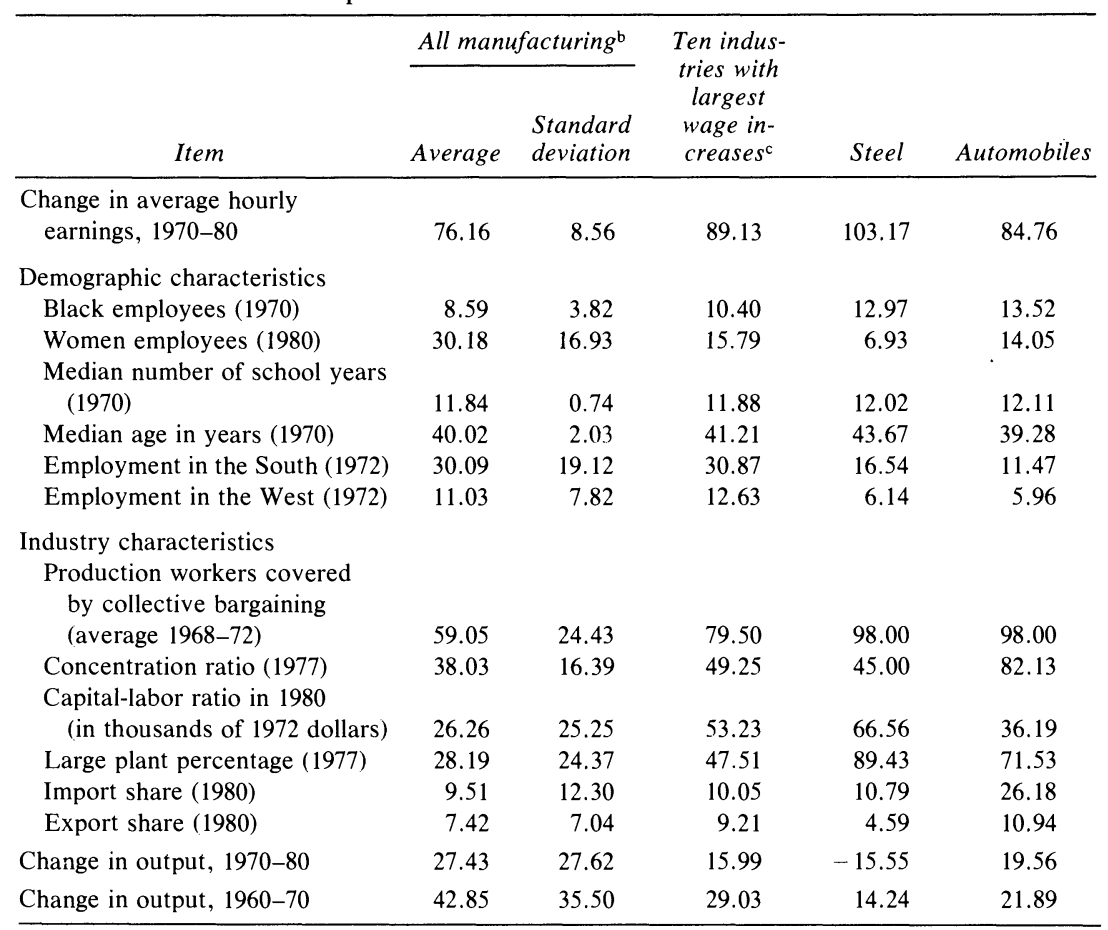

Source: See appendix for data sources and definitions.

a. In this table and the following, percentage changes are calculated as the difference in logs.

b. In this and subsequent tables, "manufacturing" refers to the sample of fifty-seven industries listed in table 2.

c. For the ten industries with the highest average hourly earnings increases during 1970-80, see table 2 .

Similarly, employment growth in these industries over the 1970s remained flat, while on average in the sample it increased by 3.1 percent. ${ }^{52}$

\section{REGRESSION ANALYSIS}

To test the theory more formally we have estimated a set of regressions explaining industry wage levels and changes with reduced-form specifications. We follow much of the literature in relating wages to independent variables depicting industry and worker characteristics. ${ }^{53}$ Since workers

52. During the 1960s, average manufacturing employment increased by 15.3 percent versus only 3.9 percent in the industries whose wages increased rapidly the following decade.

53. This approach does not explicitly model the structural relationships determining the prices of particular characteristics. 
are imperfect substitutes for one another, their wages depend on their education, experience, human capital, and skills. ${ }^{54}$ Since there are impediments to the mobility of workers between industries, such industry-specific characteristics as job security, safety, the degree of unionization, concentration, regional location, and import competition will also affect wages.

The slow game theory suggests the inclusion of other categories of variables. First, the regressions should contain empirical proxies to measure the lumpy, specific, long-lived capital that the theory suggests will exercise a crucial influence on relative wage behavior. Since large plants offer significant economies of scale in production and a "lumpy", production process, the proportion of workers in large plants (those with more than 1,000 workers), $P L P$, could capture these attributes. Industry concentration ratios, $C O N$, could also indicate scale economies. Exit barriers will be significant if capital in the industry is long-lived and industry-specific. A valid measure of average capital life is the ratio of the value of fixed capital to depreciation, $K A G E$. In addition, it seems plausible to assume that the higher the capital intensity (as measured by the capital-labor ratio) of production is, the less mobile (more industryspecific) capital is likely to be. Thus the capital-labor ratio, $K L$, is also a candidate for inclusion.

A second group of variables is suggested by the slow game hypothesis that the response of wages will depend on the relative income shares of capital and labor and the elasticities of substitution and product demand. Obtaining these parameters from time series structural models for each industry in the sample lies beyond the scope of this study. ${ }^{55}$ Moreover,

54. Daniel S. Hamermesh and James H. Grant, "Econometric Studies of Labor-Labor Substitution and Their Implications for Policy," Journal of Human Resources, vol. 14 (Fall 1979), pp. 518-42. Hamermesh and Grant have reviewed sixteen studies of laborlabor substitution, all of which specify that different categories of workers, grouped by sex, race, education, age, or production/nonproduction, are imperfect substitutes in aggregate production functions.

55. Freeman and Medoff have demonstrated that substitution between production labor and other inputs is generally lower in union than nonunion settings. Thus the proportion of unionization variable itself may be a useful proxy for the initial (long-run) elasticity of the demand for union labor. Richard B. Freeman and James L. Medoff, "Substitution Between Production Labor and Other Inputs in Unionized and Nonunionized Manufacturing," Review of Economics and Statistics, vol. 64 (May 1982), pp. 220-33. See also Freeman and Medoff, "The Impact of the Percentage Organized on Union and Nonunion Wages," Review of Economics and Statistics, vol. 63 (November 1981), pp. $561-72$. 
in general, as we have shown above, nonlinear combinations of these variables will determine the response.

If, on the other hand, Leontief production functions were assumed ex post, as demonstrated above, the rise in wages would be related to average quasi-rents (profits) per worker. The target for workers' scooping would be $r(K / L)$. Thus average profits per worker previous to slow game could be used in the regressions. In addition, provided the elasticity of demand is greater than the elasticity of substitution, as we have shown above, there should be a positive relationship between the income share of capital evaluated at the long-run equilibrium (that is, prior to the slow game) and the subsequent rise in wages during slow game. Third, the exogenous shocks that induce slow game should be modeled explicitly. Conceptually these could be either general (economywide) or sectorspecific shocks. In a cross-sectional analysis taken at a point in time, however, the economywide shocks are by definition identical for all industries, and thus they cannot be entered explicitly in the regression. By estimating cross-sectional regressions at different times during which different economywide conditions prevailed, however, we hope to discern the impact of such disturbances. We model industry-specific shocks by inserting a variable that multiplies industry growth over the previous decade by the capital-labor ratio.

As will be evident, our regressions entail several compromises necessary for empirical work. Nonetheless, as we shall show, they offer considerable support for the relevance of the slow game theory.

\section{VARIABLES}

The variables used in the regressions and the coefficients to be expected include:

\section{Slow Game Variables}

$-K L$ (fixed capital per employee) should not have a significant coefficient under competitive conditions; however, in the slow game it would be positively associated with wages.

$-K A G E$ (ratio of value of fixed capital to depreciation) should not be significant in conventional theory; in slow game it should have a positive effect. 
$-K L^{*} D O$ (interaction of the capital-labor ratio and industry growth over the previous decade) should have a negative coefficient in slow game, when slow demand growth will be associated in capital-intensive industries with high wages.

$-r(K / L)$ (profits per worker) could be positively associated with wage increases in end game.

$-S K$ (the initial share of capital in value-added) should have a positive coefficient in slow game, provided that the elasticity of demand is greater than the elasticity of substitution. Under normal circumstances it should not be significant.

\section{Conventional Variables Related to Slow Game}

$-U N$ (proportion of union members) has a positive coefficient, which should increase in slow game.

$-P L P$ (proportion of workers in plants with more than 1,000 workers) is expected to have a positive coefficient to the degree that working conditions in such plants are unpleasant enough to facilitate unionization (and thus nonunion employers keep wages high to discourage unionization) or union militancy. ${ }^{56}$ In the slow game, the coefficient should increase.

- CON (concentration ratio, or proportion of total output accounted for by the four largest firms) could be positive if concentration implies higher profits, some of which are reflected in wages, or negative if oligopsonistic firms can drive down wages ${ }^{57}$ To the degree that $C O N$ reflects exit barriers and scale economies (that is, lumpiness), the coefficient should become positive in slow game.

56. See John E. Kwoka, "Monopoly Plant and Union Wage Effects on Worker Wages," Industrial and Labor Relations Review, vol. 36 (January 1983), pp. 251-57; Stanley Masters, "An Interindustry Analysis of Wages and Plant Size," Review of Economics and Statistics, vol. 51 (August 1969), pp. 341-45; and F. M. Scherer, "Industrial Structure, Scale Economies, and Worker Alienation," in Robert Masson and P. David Qualls, eds., Essays on Industrial Organization in Honor of Joe S. Bain (Ballinger, 1976), pp. 105-21.

57. See Kwoka, "Monopoly Plant," for a survey of the studies on the impact of concentration on wages. See also Thomas A. Pugel, "Profitability, Concentration and the Interindustry Variation in Wages," Review' of Economics and Statistics, vol. 62 (May 1980), pp. 248-53; Salinger, "Tobin's $q$, Unionization, and the Concentration-Profits Relationship"; and Leonard W. Weiss, "Concentration and Labor Earnings," American Economic Review, vol. 56 (March 1966), pp. 96-117. 


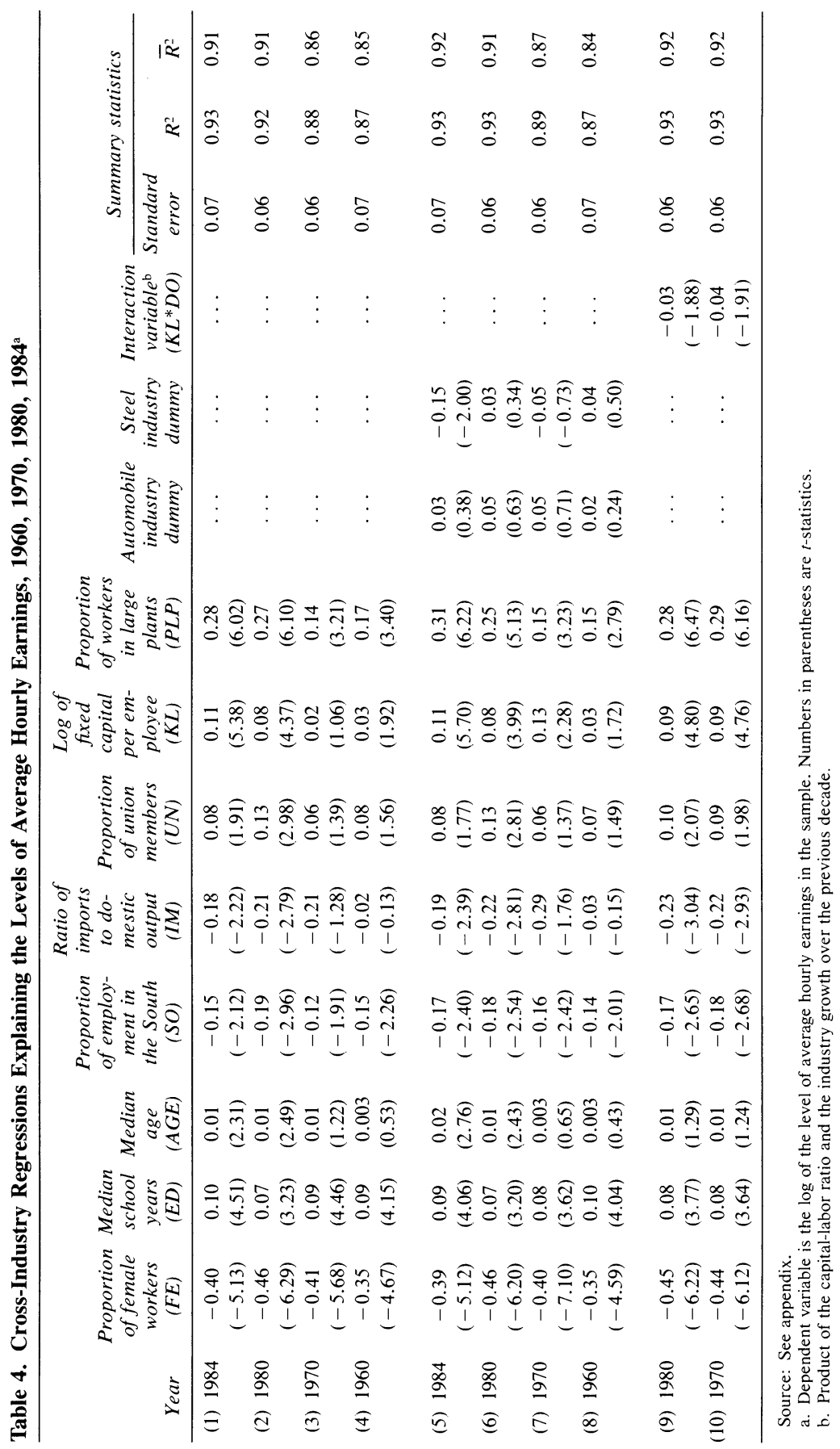




\section{Conventional Variables}

$-F E$ (the proportion of women) is expected to exert a negative impact on wages because of discrimination and female labor force participation characteristics.

$-E D$ (the median number of school years) is expected to have a positive sign because of returns to general human capital.

$-B L$ (proportion of blacks) could have a negative coefficient reflecting employment discrimination.

$-A G E$ (median age) has a positive coefficient indicating returns to experience.

- IM (ratio of value of imports to domestic production) has a negative coefficient to the degree that international competition exerts a downward influence on wages.

$-E N$ (ratio of consumption of energy to output in 1972 dollars) has, in theory, no necessary relationship to wages; however, it may be associated with higher wages in a period of energy shocks (assuming that energy and capital are complements).

- SO (proportion of employment located in the South) could be negative to reflect lower costs of living.

\section{COLA Variable}

$-C O L$ (proportion of workers covered by COLAs) should have a positive coefficient if, as the institutionalist interpretation would have it, COLAs contributed to high relative wages in the 1970 s.

A detailed description of the variables and their sources is provided in the appendix.

\section{EMPIRICAL FINDINGS}

Consider the regressions reported in table 4 explaining (the logarithms of) average hourly earnings in $1960,1970,1980$, and $1984 . .^{58}$ Overall the

58. In regressions explaining the logarithm of average hourly earnings, $C O N, B L, E N$, and $S K$ were generally not found to be significant. While $K A G E, E N$, and $r(K / L)$ were significant and behaved according to the slow game hypothesis, the significance of these variables was removed when $K L$ was introduced into the regressions. They have therefore been dropped from the regressions reported in table 4 . The role of $C O L$ will be examined below. 
regressions perform satisfactorily, accounting for between 87 and 93 percent of the overall variance, with standard errors ranging from 6 to 7 percent. The coefficients have reasonable orders of magnitude that accord with those in other studies. Consider equation 1, explaining average hourly earnings in 1984 , for example. It suggests that, everything else being equal, female earnings were 60 percent of male earnings. ${ }^{59}$ Each one-year increase in the median schooling of the labor force increased wages by 10 percent. ${ }^{60}$ Each additional year of median age (experience) raised wages by 1 percent. Labor in the South was about 15 percent cheaper than elsewhere in the United States. Each 1 percent increase in the proportion of workers in large plants raised wages by 0.28 percent. ${ }^{61}$ Each 1 percent increase in the capital-labor ratio raised wages by 0.11 percent. Each 1 percentage point increase in the share of unionized labor raised wages by 8 percent.$^{62}$ Finally, a 1 percent increase in the share of imports lowered wages by 0.18 percent. ${ }^{63}$

A comparison of the coefficients over the twenty-four-year period indicates that they support the expectations of the slow game theory. Recall that, as measured by the Federal Reserve Board, capacity utilization in each of the sample years $(1960,1970,1980$, and 1984) was similar. Thus cyclical effects are unlikely to account for differences in the coefficients. In the 1960 and 1970 regressions, $K L$ has a small

59. In the 1969 census data, annual mean female earnings were 55.7 percent of male earnings for full-time earners who worked 50-52 weeks. In 1979, similar female earnings were 52 percent of those of males.

60. This accords quite closely with the results in C. T. Haworth and D. W. Rasmussen, "Human Capital and Inter-Industry Wages in Manufacturing," Review of Economics and Statistics, vol. 53 (November 1971), pp. 376-80.

61. See Kwoka, "Monopoly Plant," and Masters, "An Interindustry Analysis," for studies of this effect.

62. For a comprehensive review of the evidence of the effect of unions, see C. J. Parsly, "Labor Union Effects on Wage Gains: A Survey of Recent Literature," Journal of Economic Literature, vol. 18 (March 1980), pp. 1-31.

63. See Stephen A. Rhoades, "Wages, Concentration, and Import Penetration: An Analysis of the Interrelationships," Atlantic Economic Journal, vol. 12 (July 1984), pp. 23-31. Rhoades found strong support for the hypothesis that imports reduce profit margins. See also Howard P. Marvel, "Foreign Trade and Domestic Competition," Economic Inquiry, vol. 18 (January 1980), pp. 103-22; Thomas A. Pugel, "Foreign Trade and U.S. Market Performance," Journal of Industrial Economics, vol. 29 (December 1980), pp. $119-29$. 
coefficient and, in accord with the agnosticism of conventional theory, is not statistically significant. Under usual circumstances unions do not capture normal rates of return. On the other hand, in the slow game, incentives may change. Between 1970 and 1980 the coefficient on $K L$ became highly significant, as our theory would predict. In addition, the coefficients on unionization and the large plant variables doubled in size and increased in significance. To capture industry-specific slow game effects, the interactive variable, the product of output growth over the previous decade and the capital-labor ratio $\left(K L^{*} D O\right)$, has been entered in regressions 9 and 10 . Both verge on statistical significance and have the negative coefficient that the slow game theory would predict.

\section{OTHER VARIABLES}

Between 1960 and 1970, the growing internationalization of the U.S. economy increased the importance of imports as a source of downward pressure on wages. Any given import share in 1970 had a greater negative impact on wages in 1970 than it did in 1960. Note the much larger (in absolute magnitude) and more significant coefficient on $I M$ in equation 3 for 1970 than in equation 4 for 1960 . This change could occur if imports and domestic products became closer substitutes over time.

During the 1960s demographic factors exerted fairly constant influences (note how similar the other coefficients in equation 3 are to those in equation 4). During the 1970s, however, the dramatic shifts in the composition of the U.S. labor force affected relative wages quite considerably. The large influx of educated, female, and young workers depressed the earnings of such workers. Compare equations estimated for 1970 and 1980, and note the decline in the coefficients on the proportion of women and median years of schooling and the increase in the significance of the variable measuring median age. These results accord with other research findings. Richard B. Freeman and Finis Welch have concluded that the size of the baby-boom cohort has reduced the relative earnings of younger workers. ${ }^{64}$ James H. Grant and Daniel

64. Richard B. Freeman, "The Decline in the Economic Rewards to College Education," Review of Economics and Statistics, vol. 59 (February 1977), pp. 18-29; Finis Welch, "Effects of Cohort Size on Earnings: The Baby Boom Babies' Financial Bust," Journal of Political Economy, vol. 87 (October 1979), pp. S65-97. 
S. Hamermesh have found that increases in female labor force participation have reduced the relative earnings of women and young men. ${ }^{65}$

Apparently some of the declines in the relative wages of certain demographic groups over the decade of the 1970s are not permanent and reflect only the transitory requirements of absorbing those groups into the labor force. Between 1980 and 1984 the coefficients on age, schooling, and the proportion of females all returned to their 1960 and 1970 levels. On the other hand, while the premium paid to older workers declined somewhat, it remained higher than in the earlier decades. The coefficient on unionization declined, but, as of 1984, capital-labor ratios and the proportion of workers in large plants affected wages even more than they had in 1960 or 1970.

\section{AUTOS AND STEEL}

Equations 5 through 8 report the previous formulation but with steel and automobile wages indicated by dummy variables. ${ }^{66}$ Considering how frequently the behavior of auto wages is alleged to be idiosyncratic, these results are quite surprising. The coefficients on the independent variables are generally not greatly affected by dropping steel and autos from the sample. In none of the years are mean wages in autos significantly different from those forecast by the equation. The error in forecasting automobile wages increased from 2 to 5 percent between 1960 and 1970, remained at 5 percent in 1980, and was only 3 percent in 1984. Steel wages, on the other hand, were more volatile relative to their forecast levels, shifting from a positive error of 4 percent in 1960 to a negative error of 5 percent in 1970, a positive error of 3 percent in 1980, and a statistically significant negative error of 15 percent in 1984 . The errors in the forecasts for steel wages suggest that a special interpretation of industry wage behavior is warranted; the automobile wage behavior,

65. James H. Grant and Daniel S. Hamermesh, "Labor Market Competition among Youth, White Women and Others," Review' of Economics and Statistics, vol. 63 (August 1981), pp. 354-60. See also David C. Stapleton and Douglas J. Young, "The Effects of Demographic Change on the Distribution of Wages, 1967-1990," Journal of Human Resources, vol. 19(Spring 1984), pp. 175-201; Lucy B. Mallan, "Labor Force Participation, Work Experience, and the Pay Gap Between Men and Women," Journal of Human Resources, vol. 17 (Summer 1982), pp. 437-48.

66. This procedure is equivalent to dropping observations for these variables from the estimation sample and then forecasting their levels out of sample. 
on the other hand, indicates that automobile wages are driven by forces similar to those that affect wages elsewhere in U.S. manufacturing.

\section{CHANGE EQUATIONS}

Despite their satisfactory performance, the formulations reported in table 4 may have some deficiencies. Several variables may be biased as a result of simultaneity. While a high share of imports could depress domestic wages, high domestic wages could raise imports. Similarly, a high capital-labor ratio could raise wages (because of its effect on the marginal product of labor), but high wages could induce the use of more capital-intensive techniques.

In addition, the levels specification fails to test explicitly for the statistical significance of the shifts in the coefficients over time. Both of these defects are remedied in table 5, where changes over particular periods are regressed against independent variables measured either just prior to or in the initial year of the observation period. This procedure should reduce the problem of simultaneity bias. Thus, for example, while high wages in 1970 may induce a large increase in imports in 1970, there is less reason to expect that a large wage change over the decade of the 1970s would be associated with a large import share in $1970 .{ }^{67}$ Note that in an equation on the first differences in the dependent variable, the coefficients on the level variables provide estimates of changes in the coefficients. ${ }^{68}$

A set of equations explaining first differences in average hourly pay is provided in table 5.69 The results in these regressions are similar to

67. This assumes that imports in 1970 were unlikely to be affected by expectations about relative wages for periods as long as a decade in advance.

68. Assume the specification $\operatorname{Ln} W_{i}=a C_{i}$. Taking derivatives of both sides: $\mathrm{d} \operatorname{Ln} W_{i}=$ $a \mathrm{~d} C_{i}+\mathrm{d} a C_{i}$. Thus in an equation in which wages are expressed as first differences in the logs, coefficients on changes in the variable provide estimates of the original level effect (that is, $a$ ), whereas the coefficient on the level is an estimate of the change in the coefficient.

69. If variables for changes in $P L P, I M$, and $K L$ are included in this specification, they do not affect coefficients on the remaining variables. The exception is the change in $F E$ $(D F E$ ) between 1970 and 1980 , which is significantly (negatively) correlated with $F E$ in 1970. Including $D F E$ in the regression makes the coefficient on $F E$ more negative and statistically significant. It does not, however, affect the remaining coefficients. Again we do not report our estimates using several of the end game proxies discussed above. We obtain positive and significant results with $r(K / L), E N$, and $K A G E$. However, in each case, 


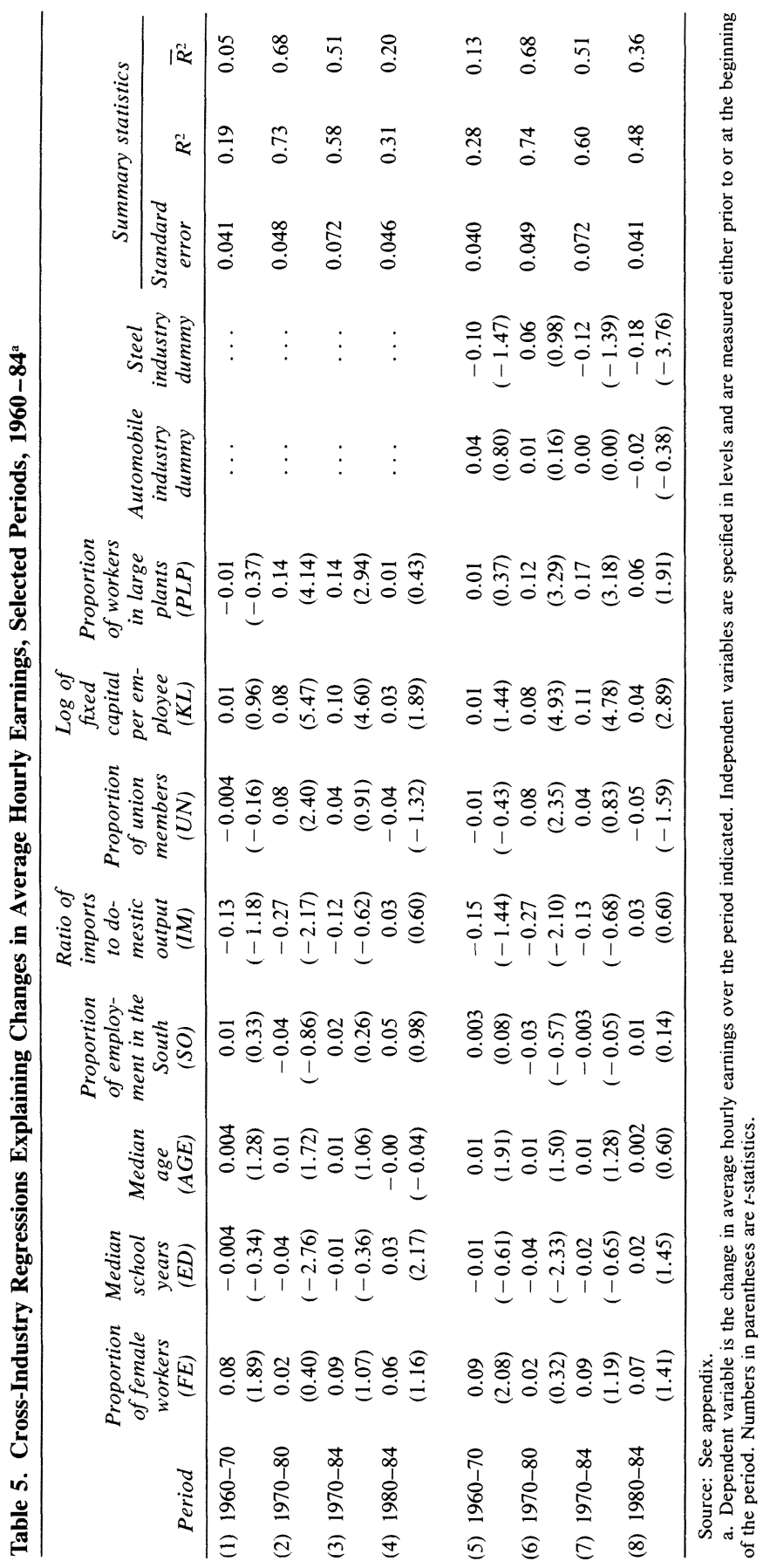


those in table 4 . Very few of the variables help explain wage changes between 1960 and 1970. In equation 1, only the coefficient of $F E$ is significant. There is also some indication of statistically important effects for imports and capital-labor ratios. Despite the low $R$-squared, the equation has a relatively small standard error, indicating that over the 1960 s there was little variation in relative wages. In the 1970s, on the other hand, the variables as specified in equation 2 in table 5 afford a powerful explanation for wage changes over the decade. They account for 73 percent of the overall variance, with a standard error of 4.8 percent. Statistically significant changes are indicated for the effects of schooling, imports, unionization, the capital-labor ratio, and large plants. In addition, if $S K$ for 1970 is added to this equation (not reported), the $R$-squared increases to 0.75 and the coefficient on $S K$ is positive with a $t$-ratio of 1.8 -again, evidence supporting the slow game scenario under the assumption that the elasticity of demand is greater than the elasticity of substitution..$^{70}$

Reversals in the impact of education, the proportion of union workers, and the proportion of workers in the South from 1980 to 1984 are indicated in equation 4. Thus between 1970 and 1984 (equation 3) the significant changes in the coefficients are confined to the variables for the capital-labor ratio and large plants. There is also some indication of an increased effect for age. The slow game variables provide most of the explanation.

The remaining four equations introduce dummy variables for automobiles and steel into the equation. The equation accounts for the increase in relative average hourly wages in automobiles of about 8 percent during the 1970s and 10 percent between 1970 and 1984. On the other hand, the rise in steel wages between 1970 and 1980 is some 6 percent larger than can be explained-supporting the suggestion in our case study above that specific end game variables were at work.

Equation 8 indicates an unusual decline (an error of -18 percent) in relative steel wages between 1980 and 1984 .

when $K L$ is introduced into the regressions, these variables lose their significance. Multicollinearity is a problem in trying to obtain joint estimates with these variables. The correlation between $K A G E$ and $K L$ using 1980 data was 0.64 . This suggests that capital intensity, as judged by the capital-labor ratio, and long-lived capital are typically associated.

70. If $S K$ is substituted for $K L$ in the equation explaining the change in hourly earnings from 1970 to 1980 , it has a $t$-ratio of 4.1 and a coefficient of 0.27 , and the overall equation has a standard error of 0.053 . 


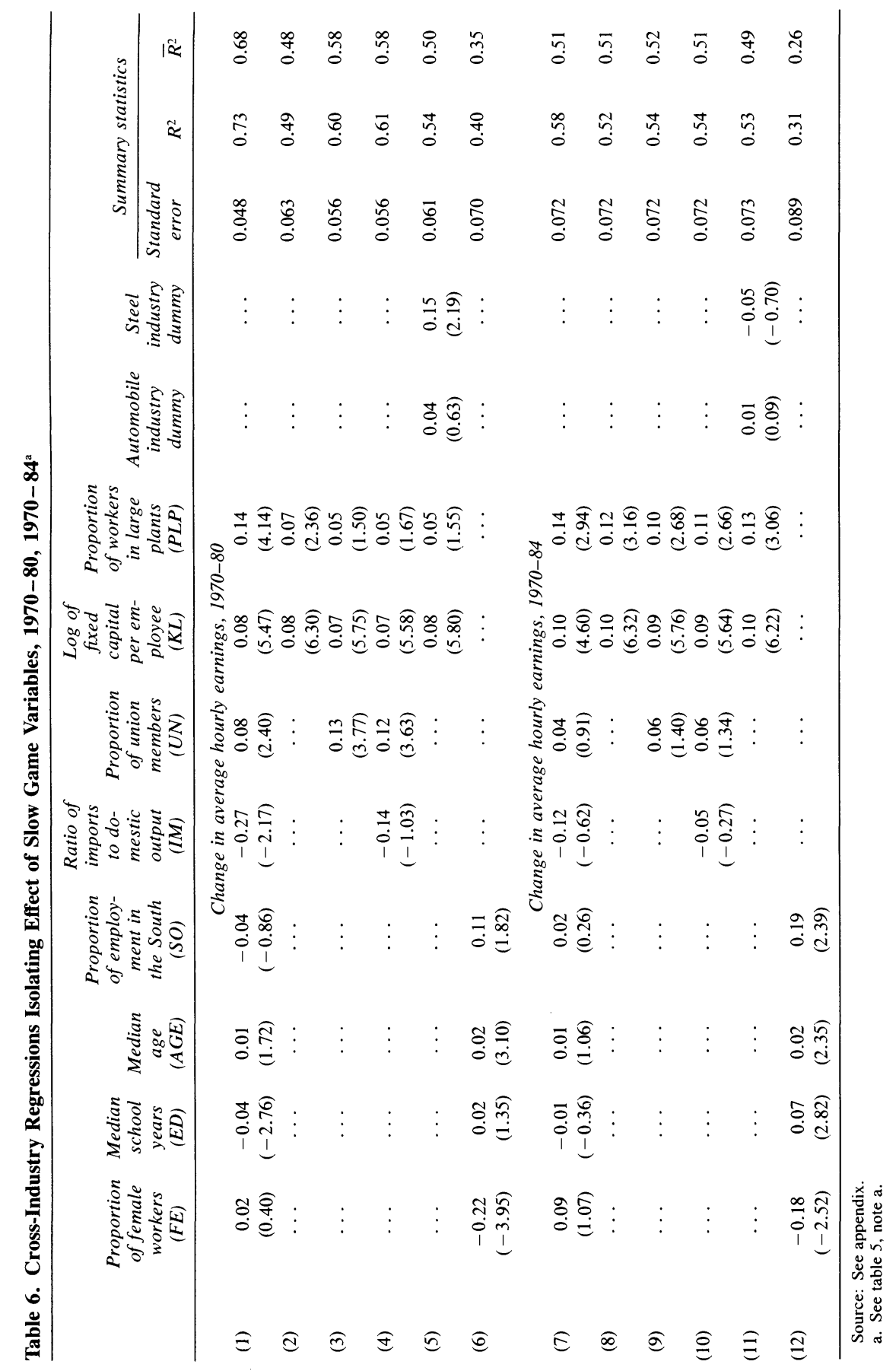


How much of the overall variance in wage growth is accounted for by the slow game variables ( $P L P$ and $K L)$, and how much by the more conventional demographic factors? A rough answer can be gauged by examining the regressions reported in table 6 . The complete equation (equation 2 in table 5), reproduced as equation 1 in table 6 , explains 73 percent of the variance. Equation 2, with just $K L$ and $P L P$, accounts for 49 percent of the variance. The addition of $U N$ raises the $R$-squared to 0.61 . On the other hand, equation 6 , with just the demographic variables ( $F E, E D, A G E$, and $S O$ ), accounts for 40 percent. This confirms the importance of both the slow game and the demographic explanations for relative wage dispersion during the 1970s. Demographic variables become much less important, however, when the period 1980-84 is included in the sample. Over the fourteen-year period 1970-84 (equation 8), the variance explained by just $K L$ and $P L P$ of 0.52 is virtually the same as the 0.58 in the complete specification. It is remarkable that a regression with just these two variables can track average hourly earnings in the U.S. automobile industry between 1970 and 1984 with an error of just 1 percent.

In 1980 average hourly wages in the automobile industry were 32.8 percent (in the logs) higher than hourly wages in the rest of manufacturing. Equations 2 in table 4 and 2 in table 5 have been used to quantify the contributions of each independent variable. As reported in table 7, about 7.4 percentage points are due to the relatively low employment of females, 3.5 to the low share of production in the South, and 1.7 to the higher median education of employees. Import pressures kept wages 3.54 percent lower than they would otherwise have been. About half the differential is explained by $P L P$ and $K L$. The change in auto wages between 1970 and 1980, however, is better accounted for by the extent of unionization, the capital-labor ratio, and large plants. In the case of steel wages (equations 1 and 2 in table 7), of all the demographic variables only the relatively high average age of the work force exerted a substantial impact in the rapid wage rise during the 1970 s. The remaining changes are ascribed to the high $K L$ and $P L P$ values.

\section{COMPENSATION}

The wage variable we have examined thus far is for average hourly earnings. While the changes in this indicator of wages correspond closely 


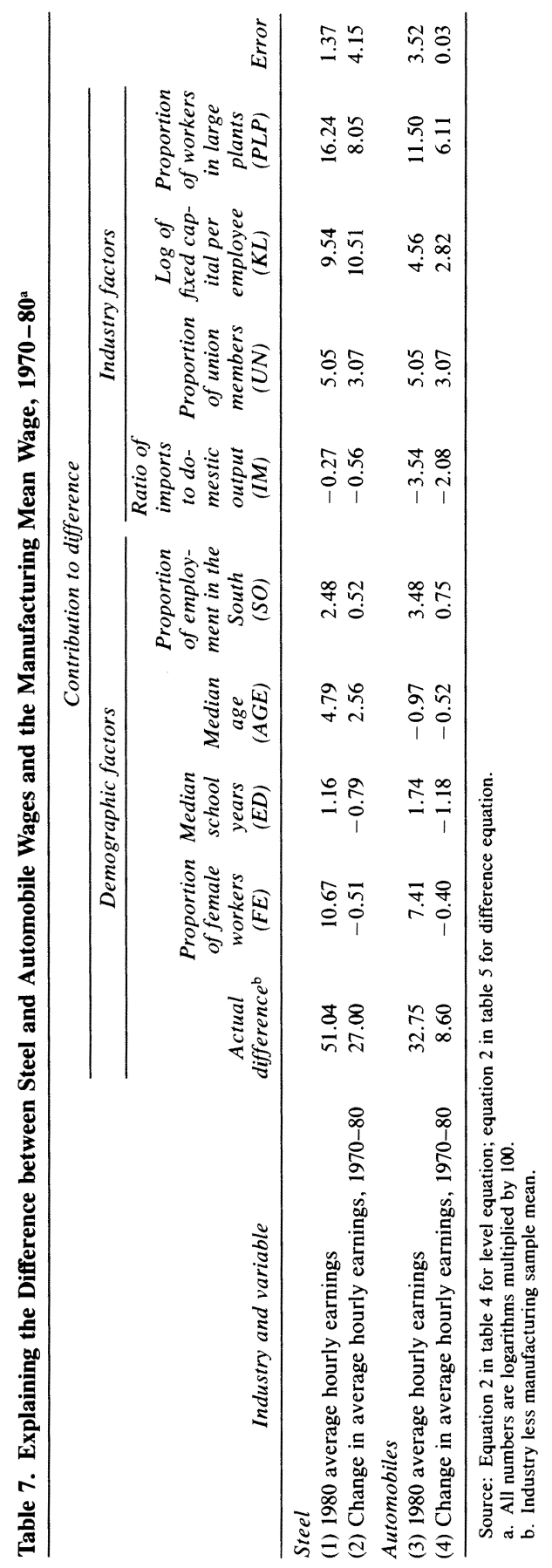


with those in total compensation overall (with a correlation of 0.88 ) during the 1970s, the increase in relative total compensation in the automobile industry (14 percent) was larger (and more relevant to labor costs in the industry) than the increase in relative average hourly earnings ( 8 percent). Accordingly in table 8 we have reestimated the regressions using changes in average compensation and levels of compensation as the dependent variables. The changes in the coefficients on the level equations 1 and 2 indicate shifts in the discount on female wages and an increase in the return to age. However, they do not indicate declines in the return to schooling or in the impact of the South, as in the hourly pay regressions. $U N$ fails to have a significant effect in these regressions, and its role is taken over by the $C O N$ variable. However, the same major rise in the coefficients on $K L$ and $P L P$ is evident in these results.

It is noteworthy that the regression explains out of sample the rise in relative compensation in automobile wages with an error of just 1 percent, and the level of auto compensation in 1980 with an error of just 3 percent. The error in tracking steel compensation over the decade is again considerably larger -7 percent.

\section{OTHER TESTS}

It is of interest to test the additional power of the explanation that accounts for wage shifts in the 1970s in terms of COLA-plus contracts.

A second data set includes variables at the two-digit SIC level. Reducing the number of industries by going to this high level of aggregation severely reduces degrees of freedom but allows testing for the role of COLAs. These regressions (not reported) gave similar results to those above. Seventy-eight percent of the variance of average hourly wage growth over the 1970s can be explained by four variables: $F E, E D$, $K L$, and $C O N$. The $C O L$ variable was not significant. ${ }^{71}$ This specification has an error of 5.8 in primary metals compensation and almost no error in the changes in automobile compensation.

71. Freeman and Medoff note, "According to our estimates, in manufacturing, COLA provisions contributed only a modest amount to the rising union advantage: union workers without COLA clauses did nearly as well as union workers with such clauses." What Do Unions Do?, p. 54. 


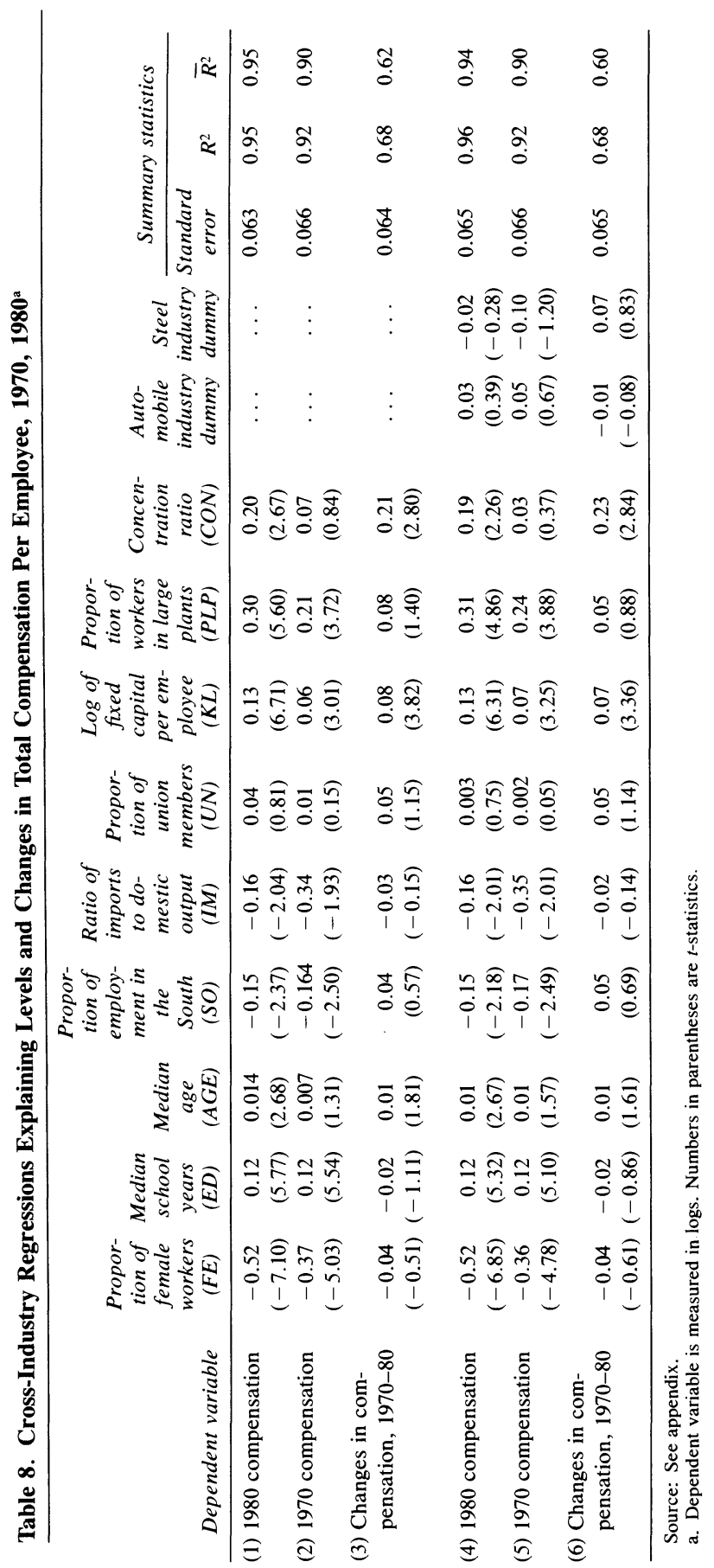


INTERACTION EFFECTS

Our theory anticipates that unionized and nonunionized industries will react differently in the slow game. But our efforts at inserting multiplicative variables, for example, $U N^{*} P L P, U N^{*} K L$, and $U N^{*} I M$, failed to provide robust results, in part because of the high multicollinearity between these multiplicative variables and their components. This finding could indicate that emulation effects are important in union behavior so that even in cases where unions do not have high membership proportions, industries behave "as if they were unionized," in order to ward off the threat of unions..$^{72}$ Emulation tends to be greatest with large firms. Indeed Freeman and Medoff report that the union differential varies inversely with plant size. ${ }^{73}$ But it is likely that the weak performance of the union variable is due to the fact that most of the industries in the sample are highly unionized. Thirty-eight of the fifty-seven industries in the sample are more than 50 percent unionized, and only nine have less than 40 percent of their production workers in unions.

In summary, compared with preceding decades, the 1970s was a period of slower overall growth, much lower capacity expansion of large structures, growing import penetration in heavy industries, increasing regulations restricting investment in high-pollution sectors, and substantial energy shocks. All of these developments reduced demand for the products of heavy industry and, as we have shown, provided reasons to expect an increase in union wage demands in heavy industry.

In response to the slow game, wage increases were, in fact, particularly rapid in industries with high capital-labor ratios and large plants. The phenomenon was pervasive, with the automobile industry behaving in a typical and predictable fashion given wage behavior elsewhere in manufacturing.

On the other hand, while some of the rise in steel wages can be accounted for in the cross-section estimates, large residuals remain. In particular, the recent declines in steel wages are extremely unusual. The regressions support the view that by 1984 , the steel industry had entered the end of the end game.

72. For support of this view, see Freeman and Medoff, What Do Unions Do?, chap. 10. See also S. Rosen, "Trade Union Power, Threat Effects and the Extent of Organization," Review of Economic Studies, vol. 36 (April 1969), pp. 185-96.

73. Freeman and Medoff, What Do Unions Do?, p. 153. 


\section{Productivity Declines}

Wage increases are often regarded as a reward for greater productivity. Yet in our sample of fifty-seven manufacturing industries, those with the fastest wage growth in the 1970s were also those with the slowest growth in productivity and the greatest productivity declines. Over the 1970 s, for example, there was a negative correlation $(-0.245)$ between the growth in value added per employee and average hourly pay in the sample.

Changes in output per employee reflect both the impact of changes in the capital-labor ratio and disembodied technical progress. The contribution of changes in capital per employee can be estimated by multiplying the share of capital by changes in the capital-labor ratio. The residual productivity growth can then be estimated by subtracting the contribution of increases in the capital-labor ratio from the overall rise in output per employee. Using data on the 1970 share of capital in value added and the change in the capital-labor ratio between 1970 and 1980, we have estimated residual productivity growth for each of the fifty-seven industries in our sample. The correlation between the growth in average hourly wages between 1970 and 1980 and the residual productivity variable is $-0.35 . .^{74}$

Our finding has been corroborated. In his study of the productivity slowdown across U.S. industries, Baily adjusted the growth in output per manhour for both changes in the capital-labor ratio and changes in capacity utilization. ${ }^{75}$ Baily estimated the (adjusted) productivity slowdown in twenty-one two-digit manufacturing industries by subtracting the annual (adjusted) average growth in productivity between 1953 and 1973 from the annual (adjusted) average productivity growth between 1973 and 1980. The correlation between Baily's growth slowdown measures and average hourly earnings increases in these twenty-one industries over the $1970 \mathrm{~s}$ is $-0.52 .{ }^{76}$ The industries with the largest wage increases had the largest slowdowns in productivity growth.

How can this behavior be explained? In our discussion of the slow

74. Changes greater than 0.265 are significant at the 5 percent level.

75. See Baily, "The Productivity Growth Slowdown," pp. 423-59.

76. The data for the productivity slowdown are to be found in column 3 in table 2 of Baily, "The Productivity Growth Slowdown," p. 437. 
game we suggested that unions may use their increased power in slow game to demand more than just higher wages. In particular, in cases where working conditions are associated with considerable disutility, work rules may be altered if the demand for labor becomes less responsive to its wage, including the "shadow" wage costs of such rules. If the union hand is strengthened by a decline in the demand elasticity for union labor, featherbedding may also be increased to preserve union jobs. A corollary of rising relative wages, therefore, could be an unusual decline in productivity growth.

In his study, Baily reports a strong association between the slowdown in adjusted productivity growth and capital intensity (as measured by the nonlabor share of income) ${ }^{77}$ His explanation focuses on the premature retirement of obsolete capital. However, if capital were to be speedily retired and plants were driven by the energy shocks close to shutdown, one would not expect relatively rapid increases in wages. On the other hand, if new investment were expected to be lower and devoted to saving energy rather than labor, unions might react by demanding and receiving higher relative wages and more attractive work rules. Thus the slow game may be the link between the anomalous behavior of productivity and wage growth. It provides another theoretical explanation for the association found by Baily between the productivity slowdown and capital intensity.

\section{Applications, Implications, and Conclusions}

During the late 1960s and early 1970s, real wages in European manufacturing increased more rapidly than was warranted by productivity growth and terms-of-trade changes. ${ }^{78}$ While there is a legitimate debate about whether real wages in Europe are still above levels warranted for full employment, the persistence of these levels in a period of slow overall growth and rising unemployment has not been adequately explained.

The conventional account of this behavior is analogous to that in the United States for wages in steel and automobiles: workers became used

77. Ibid.

78. See, for example, Jeffrey D. Sachs, "Wages, Profits, and Macroeconomic Adjustment: A Comparative Study,” BPEA, 2:1979, pp. 269-319. 
to a certain increase in real wages and demanded that increase regardless of economic circumstances. But this account of European wage behavior is as unsatisfactory as it is for U.S. autos and steel. Workers presumably seek the highest wages they can get at all times. If they were able to obtain higher income shares in the early 1970s, when warranted wage growth declined, why were they not able to obtain them earlier? At a first reading, the facts of the European situation conform to slow game. Capacity-expanding investment in European manufacturing slowed appreciably after 1973 . The high levels of capacity utilization now prevailing in Europe are associated with increased unemployment levels. Moreover, the implementation in the early 1970 s of various pieces of social legislation conferring virtual tenure on employees corresponds at the macroeconomic level to featherbedding at the industry level. ${ }^{79}$ An extension of the slow game interpretation to an economywide or sectorwide application appears a worthwhile topic for further research.

An examination of relative union wages in other periods also warrants investigation. As estimated by George Johnson, there was a massive rise in the union wage differential in the 1930s-a period in which end game developments would have also been relevant. ${ }^{80}$

Our results have implications for other empirical work. We have shown in our theoretical analysis how high wages can be associated with both very high and very low levels of profitability (or of Tobin's $q$ ). Empirical estimates of the link between unionization and profitability need to take account of the nonlinear relationship likely to be found. We have found several shifts in the impact of demographic variables between 1980 and 1984. New (and more extensive) investigations of the returns to schooling in recent data appear warranted.

The work of Gene M. Grossman in estimating the link between imports and domestic employment is a considerable advance over conventional input-output estimates. However, as the end game theory shows, in capital-intensive industries, changes in competitiveness and wages may be associated negatively rather than positively, as such modeling assumes. ${ }^{81}$

79. See Bela Balassa, "The Economic Consequences of Social Policies in the Industrial Countries," Welwirtschaftliches Archiv, vol. 120, no. 2 (1984), pp. 213-27.

80. Cited in Freeman and Medoff, What Do Unions Do?, p. 53.

81. See Gene M. Grossman, "Imports as a Cause of Injury: The Case of the U.S. Steel Industry," Discussion Paper 78 (Princeton University, September 1978), and "The Employment and Wage Effects of Import Competition in the United States," Working Paper 1041 (National Bureau of Economic Research, December 1982). 
Our analysis also has two policy implications. First, if workers perceive that their industry is in decline, they may well seek wages that make decline certain. The governinent should therefore ensure that it avoids taking actions that could exacerbate these effects. In particular, providing trade protection in the form of quotas will lower the derived demand elasticity, thereby encouraging unions to demand even higher wages. Second, in end game, subsidies for declining industries are likely to flow directly from the government to labor without materially affecting the revitalization of the industry. Indeed, the end game theory indicates why wages are particularly likely to rise in public sector services with large amounts of capital (for example, railroads and subways) when growth prospects appear limited. The government should not enhance wage disparities by policies that strengthen workers' incentives to seek higher wages and thus increase the difficulties of adjustment.

\section{CONCLUSIONS}

Existing explanations for the relative wage changes in U.S. manufacturing over the past fifteen years are unsatisfactory. In principle, it is inappropriate to account for pervasive secular relative wage movements in terms of short-run inflation, business-cycle fluctuations, or industryspecific institutional arrangements. In practice, the alleged link between COLAs and increases in relative wages is not supported by the data.

The end game and slow game theories advanced here build a more satisfactory theoretical explanation and have strong explanatory power. Most popular discussions of relative wage behavior in the steel industry suggest that the wage determination process reflects an irrational lemming-like desire for extinction on the part of the participants. We have demonstrated, to the contrary, that high relative wages may be the result of declining competitiveness rather than the cause. The end game model forecasts a two-phase response to a sequence of demand declines. In the first, relative wages rise as unions harvest the quasi-rents that once accrued to capital. In the second, relative wages fall in response to the credible threat of permanent plant closings. Steel wage behavior conforms to this forecast: the first phase lasted from about 1970 to 1982; the second from 1982 to the present.

We have explained why relative wages in heavy industry could rise in response to a medium-term decline in growth prospects. In our empirical work, we have demonstrated that much of the increased 
dispersion in U.S. manufacturing wages can be explained by the increasing importance of capital intensity and plant size in raising relative wages.

Popular discussion also suggests that compensation patterns in the U.S. automobile industry have been unusual and idiosyncratic. Our regression analysis indicates that in fact the determinants of relative automobile wages are the same as those elsewhere in the manufacturing sector.

If slow game was the source of the increased dispersion in U.S. manufacturing wages over the past decade, the recent restoration of medium-term prospects for growth should reverse these relative wage patterns. There is some preliminary evidence that supports this prediction. Between 1982 and 1984, wages in unionized industries increased 2 percent less rapidly than those in the rest of manufacturing. And the dispersion in average hourly wages across manufacturing was no greater in 1984 than in 1982. Perhaps the fast game has begun.

\section{APPENDIX}

\section{Variables and Data Sources}

AGE Median age of employees in 1970, defined as the weighted sum of males and females. From U.S. Bureau of the Census, Census of Population: 1970, Subject Reports, Industrial Characteristics, Final Report PC(2)-7B (GPO, 1973).

$B L$ Proportion of black employees in industry in 1970, defined as the weighted sum of males and females. From U.S. Bureau of the Census, Census of Population: 1970, Subject Reports, Industrial Characteristics, Final Report PC(2)-7B (GPO, 1973).

CON Concentration ratio, defined as the share of value of shipments accounted for by the four largest companies in each manufacturing industry. From U.S. Bureau of the Census, 1977 Census of Manufactures, Subject Statistics, vol. I (GPO, 1981).

$D Q$ Percentage change in real output (1972 dollars) for 1960-70 and 1970-80. From U.S. Bureau of Economic Analysis, input-output tape. 
ED Median school years completed by employees, defined as the weighted sum of years attained by males and females in 1970 . From U.S. Bureau of the Census, Census of Population: 1970, Subject Reports, Industrial Characteristics, Final Report PC(2)7B (GPO, 1973).

FE Proportion of women in industry. From U.S. Bureau of Labor Statistics, Employment and Earnings, various issues.

IM Proportion of imports in industry, defined as ratio of imports to output (all in 1972 dollars). From U.S. Bureau of Economic Analysis, input-output tape.

$K L$ Capital-labor ratio, defined as gross capital stock in 1972 dollars, divided by average total employment. Capital data from unpublished data, U.S. Department of Commerce, Office of Business Analysis, Office of Research Analysis and Statistics. Employment data from U.S. Bureau of Labor Statistics, Employment and Earnings, various issues.

PLP Proportion of total employment in establishments with 1,000 or more employees. From U.S. Bureau of the Census, 1977 Census of Manufactures, Subject Statistics, vol. I (GPO, 1981). Data for 1967 were used for equations starting in 1960 and 1970. Data for 1977 were used for equations starting in 1980.

SO Proportion of employment in the South in 1972 as defined by Bureau of the Census regions. From U.S. Bureau of the Census, Census of Manufactures, 1972, Subject Series: General Summary, MC72(1)-1 (GPO, 1975).

UN Percentage of production workers covered by collective bargaining agreements. From Richard B. Freeman and James L. Medoff, "New Estimates of Private Sector Unionism in the United States," Industrial and Labor Relations Review, vol. 32 (January 1979), pp. 143-74.

Data on average hourly earnings for production workers in current dollars are from U.S. Bureau of Labor Statistics, Employment and Earnings, various issues.

Data on total compensation per employee, defined as average total salary plus employer compensation plus other employer payments and pro- 
grams, are from U.S. Bureau of the Census, 1981 Annual Survey of Manufactures, Statistics for Industry Groups and Industries, M81(AS)1 (GPO, 1983).

Data on export shares, defined as ratio of exports to output (all in 1972 dollars), are from U.S. Bureau of Economic Analysis, input-output tape.

Data on proportion of employment in the West in 1972 as defined by Bureau of the Census regions. From U.S. Bureau of the Census, Census of Manufactures, 1972, Subject Series: General Summary, MC72(1)-1 (GPO, 1975). 


\section{Comments and Discussion}

Robert M. Solow: The easiest way to explain what Colin and Robert Lawrence are up to is to translate their central thought to a more familiar context. Every schoolboy or schoolgirl knows how to analyze the profitmaximizing choice of a monopolist facing a downward-sloping demand curve and incurring-for simplicity—constant marginal costs. You draw the demand curve and the falling marginal revenue curve that runs below it. The best price lies on the demand curve at the quantity at which marginal revenue intersects marginal cost. If the demand curve shifts back isoelastically, the marginal revenue curve will shift back proportionally. The profit-maximizing monopolist will sell fewer items at a lower price, dividing his or her bad luck between price and quantity. But suppose the demand curve shifts back and at the same time becomes less elastic. Then marginal revenue relative to price is lower than it used to be at every quantity. (The ratio of marginal revenue to price is the celebrated "one minus the reciprocal of the absolute elasticity of demand."') The bright undergraduate can easily draw a diagram showing that the monopolist's price will actually be higher than it was before; the profit-maximizing quantity is then very much lower than it was before. Instead of dividing his or her bad luck between price and quantity, the monopolist raises the price and overcompensates by accepting a large reduction in quantity sold. A decrease in demand is accompanied by a rise in price.

The Lawrences' story is exactly analogous. During the 1970s and 1980 s, workers in one group of manufacturing industries managed to raise their wages relative to those of workers in other manufacturing industries, despite suffering a relative decline in product demand and in the derived demand for labor. Steel is the prototype. But all the industries 
in question are generally characterized as concentrated, capital-intensive, and unionized. The Lawrences argue that workers in those industries saw the demand curve for their labor shifting adversely, but also becoming less elastic. They responded, optimally for themselves as a group, by imposing a relative wage increase and making it stick. Employment fell more than it would have if wages had risen less, stayed the same, or fallen. But just as with the monopolist-but with collective utility taking the place of profit-the wage increase overcompensates for the fall in employment.

There is, of course, a sound of paradox in this story. But the paradox lies in the facts: relative wages did rise in a group of declining industries. There is a mythic precedent for the Lawrences' hypothesis. Once upon a time, long ago, the demand curve for labor in the deep coal mines of Pennsylvania and West Virginia more or less collapsed under the impact of competition from surface mines in the western states and advancing mechanization in the deep mines. John L. Lewis and the United Mine Workers decided more or less consciously not to resist the process, perhaps even to go along with it, even accelerate it, and to extract in return a very generous compensation package for the dwindling number of senior miners who remained. Who is to say that they were wrong to do so? The Lawrences' story may be paradoxical, but it is not outlandish.

But why should the demand curve for labor in those particular industries have rotated to become steeper while it was shifting back? The argument in the Lawrences' paper goes like this. One component, though only one, of the elasticity of derived demand for labor comes from the substitutability of labor and capital. Capital-intensive industries are very likely to be characterized by putty-clay technologies: laborcapital input proportions in new plants may be fairly sensitive to input prices, but once a plant is designed and built, the scope for input substitution diminishes sharply. The Lawrences conclude that a capitalintensive industry in decline is exactly what their hypothesis needs: the demand curve for labor shifts to the left because product demand shifts to the left, and the demand curve for labor becomes less elastic because, with no new plants being built, that component of substitutability is removed.

Is this a plausible story? To begin with, I have two constructively critical remarks to make. First, there is a possibly important element of the labor market model to which the Lawrences pay no attention; that is 
the reservation wage. (Changes in the reservation wage play the same role in the labor market that changes in marginal cost play in the familiar monopoly story.) The reservation wage for steelworkers and others is compounded out of unemployment insurance, other pension and social insurance benefits, wages in alternative employment (if any), and leisure. The effective reservation wage was no doubt changing during the 1970s and 1980s, especially as the fortunes of nondecaying industries fluctuated with the general business cycle. Other things being equal, the wage in the Lawrence sector should move with the reservation wage. Part of the reservation wage effect is accounted for by the behavior of relative wages; but I wonder if relative reservation wages may not have been changing too. If so, that ought to be factored into the analysis.

That brings me to a second point. It is a standard observation that wage differentials (high-low, union-nonunion) tend to narrow in good years and widen in bad years. Since the Lawrence sector appears to be generally high-wage, one wonders how much of the changing differential may be accounted for by this general cyclical relationship. This question would be unimportant if all industries were synchronized in their business-cycle fluctuations, or if the routine cyclical change in wage differentials were caused by the same factor that the Lawrences emphasize. There are, however, other forces at work: the hoarding of skilled labor, the greater ability of organized workers to resist wage cuts in bad years and to resist wage drift in good years, and no doubt more. Getting a grip on the purely cyclical component of the change in the relative wage structure would require some analysis of time series instead of the 1970 and 1980 cross-sections of industries. But the question should be checked out. Maybe a capacity-utilization variable could be introduced into the cross-sections.

While I am at it, I mention a doctrine-historical observation. Some of the Lawrences' formulas depend on the difference between the elasticity of demand for product and the elasticity of substitution between capital and labor. Fifty-plus years ago, Hicks pointed out that Marshall's generalization about the derived demand for anything being less elastic, the less important that thing is as a fraction of total cost holds provided the elasticity of product demand exceeds the elasticity of substitution. This seems to be the normal case, by the way. Pretty surely, the result crops up here for the same or a similar reason. Always nice to see an old friend. 
I really do not know what to say about the regression analysis. The results, as the Lawrences point out, are generally consistent with their hypothesis. (Can it really be true that there has been nothing special about the auto industry's wage behavior in recent years, where "nothing special" means that it is unnecessary even to take account of the inroads of imports and the correspondingly sharp fall in capacity utilization?) Obviously it is better that the results should be consistent with the hypothesis than not. What is not clear to me is what power this test has against the relevant alternative hypotheses, whatever they may be. The significance of the capital-intensity variable, for example, might well be compatible with other stories.

Nevertheless, I end up feeling that there is some substance to the Lawrences' model. In the case of steel wages, for instance, it seems to come down to a choice between the Lawrences and some kind of death wish. Lawrence and Lawrence make more sense any time.

Michael L. Wachter: Colin and Robert Lawrence have written an excellent paper that presents a novel approach to the puzzle of rising union wage premiums during the 1970s and early 1980s. This is a critical issue, and the paper has made an important contribution to explaining union wage behavior. The Lawrences argue that union members, determining that their industries are in decline, bargain to expropriate the difference between variable cost and price. The union members decide that their employers are not going to modernize outdated plants and are only awaiting the time when the facilities no longer help pay the fixed cost. As a quasi-rent, this differential between variable cost and price can be bargained away.

To explore the model and some of the empirical issues involved, I would like to comment on four areas. First, did the Lawrences test the end game or slow game model? Second, is such a model viable in explaining industries other than manufacturing? Third, does the end game model introduce rationality into the model in an implausible way? Finally, are there other explanations of the rising union wage premiums?

The Lawrences do not actually test the theoretical model of the end or slow game. The equations are based on a single wage equation model that is primarily useful in tracking the increasing union wage premiums. Their estimates do show increasing union wage premiums, and they do provide information on the characteristics of the industries subject to increasing premiums. 
A test of the end game or slow game model, however, needs more structure. In particular, one must estimate an output (or employment) equation for the particular industries that are presumed to have adopted an end game strategy. These equations could then be used to test for two critical hypotheses that are embedded in the end game.

First, for the end game to make sense, it must be shown that the decline in industry-specific output would have been a reasonable forecast by the parties involved in collective bargaining in the early 1970 s. Obviously, absent a pessimistic forecast of industry decline, the unions would not adopt an end game strategy. The unions' published literature might have evidence on this point. Alternatively, the more traditional strategy could be adopted-that is, to reestimate the output equation for the time period ending in the early 1970s and then to make an out-ofsample forecast for the period through 1984.

Second, it must be shown that the output decline itself was largely independent of the existence of the union wage premiums. The basis of the end game theory is that the output decline would have occurred in any case, and that the unions were responding to this environment when they sought and attained higher wage premiums.

In other words, the test of the end game hypothesis is largely dependent on results obtained from an output equation. The Lawrences have not, however, estimated such an equation. Their equations, which have the wage premium as the dependent variable, only show which industries were potentially in play as slow game or end game industries. That the Lawrences have not rigorously tested their model restricts the interpretation that the reader can make of their empirical results, but the more important contribution of their paper is the exposition of the end game model itself.

If the Lawrences' model were tested in terms of the output equations, the results might well confirm the basic hypotheses in some areas of manufacturing such as primary metals, transportation equipment, machinery, and fabricated metals. These industries had fallen on hard times by the early 1970s and have declined further over the past ten years.

Whether these developments could have been arrested by aggressive attention to wage costs is important, although difficult, to determine. If relative labor costs existing during the late 1960s had already made these industries noncompetitive, then the actions of the 1970s cannot be viewed as a new strategy, that is, a strategy designed to gain the quasirents from an industry that was dying anyway. If the premiums existing 
during the 1960s were an important part of the industries' problems, then the slow game strategy was in place much earlier than the 1970s, perhaps even from the late 1930s or the early 1950s. This, by the way, is not implausible. With respect to the industrial unions in manufacturing, the only significant period when union wage premiums declined was the 1960s. Perhaps the unions experimented with the neoclassical model of stationary premiums, found it wanting, and then continued to increase relative wages.

The second question concerns whether the model can be applied outside of manufacturing. Although the Lawrences argue that their model is not industry-specific, I do not believe that it can be plausibly applied to the other heavily unionized industries in the United States, that is, regulated sectors (such as transportation and communication), mining, and construction.

Of these three broad groupings, union wage premiums were growing most strongly in the regulated industries, which by no means conform to the end game hypothesis. They are not dying, and to the extent that employment is falling, the decline is concentrated in the unionized sectors. Deregulation and the associated direct competition from nonunion firms are the major threats to the financial health and employment levels of the unionized firms in these industries.

Thus, to explain increasing premiums in the regulated sector requires a different industry-sector story. Increasing union wage premiums cannot be viewed as a rational response by unions to a decline in employment that would have occurred in any case.

In construction, union wage premiums actually declined during the 1970s. In mining, premiums held steady. The construction story is again sector-specific. There, union wage premiums increased dramatically during the early 1970s and then declined thereafter. The interesting part of the construction story is that most of these industries are on a short contract cycle and frequently do not have COLAs. Hence the importance of COLAs to the current problems in manufacturing and regulated industries-both sectors with strong COLA clauses-should not be discarded too readily.

In construction and mining, as in the regulated industries, competition from nonunion firms is causing employment losses to unionized firms. Again, relative union wages are a key exogenous causal link.

Even absent the contradictory evidence outside of manufacturing, 
attempting to apply the end game model too broadly is not useful. The model simply cannot be used to explain economywide developments while retaining its unique characteristics. It needs to be applied to industries that are in decline, and the U.S. economy, overall, is simply not declining.

The Lawrences attempt to use the slow game version to explain the economywide evidence of the 1970s. But the 1970s, after all, were a prolonged cyclical phenomenon. And in a cyclical downturn, union assaults on the quasi-rents of the capital stock would not be a reasonable strategy. The notion that union members and their leaders are so shortsighted as to destroy their employers in the midst of a prolonged cyclical downturn is too irrational to be believable. Hence I think the case is strongest when application of the end game version of the model is limited to relevant industries in the manufacturing sector.

The third issue is the extent to which the Lawrences' story introduces rationality in an asymmetric way. The usual view is that firms and not workers have an asymmetric information advantage with respect to industry demand conditions. Ex post, it is clear that industries such as steel, autos, and machinery appear to be in a period of long-term decline. But the Lawrences' story is that farsighted unionists may have decided in the early 1970s that their employers' decline was inevitable and that a higher wage premium would secure quasi-rents with little employment or allocational effects.

But if this was the case, the unionists clearly had more insight than the managers. For example, steel industry management signed the experimental no-strike provision with the view that the industry's woes were due to strike-induced supply interruptions and not to high wages. Indeed that settlement was heralded as a forerunner of agreements elsewhere, of a labor relations system that had finally come of age.

Hence, the Lawrences' story suggests that the unions knew that the end game was in effect, but were not telling their counterparts in management, who were incorrectly processing their own private information.

Another puzzle with respect to asymmetric information concerns asymmetric power. Even if unions were interested in management's capital quasi-rents, why would union leaders assume that they could secure them? The ability of management to withstand strikes (for example, by staying open and hiring nonstrikers) was in place during the 
1970s. Unions were no better able to impose unilateral settlements then than they had been in the 1960 s. Hence, what is the basis for assuming that they could secure the quasi-rents?

Indeed, management can play the end game as well as workers can. Why did management not attempt to secure the quasi-rents from the workers? As is well known, specifically trained workers in manufacturing generate bilateral monopoly conditions that have an uncertain outcome. Workers and management are viewed as splitting that game so as to encourage efficient levels of specific training. The existence of deferred compensation and the likelihood that wages exceed marginal productivity in the later years of employment create a pool of worker rents. It is assumed that management will not renege and usurp those rents in the interest of maintaining a reputation as a good employer. If the end is in sight, however, the need to maintain that reputation is gone.

That union power at the picket line was already declining during the 1970s and that workers also owned quasi-rents are major problems for the end game model. Were unions rational agents, processing information more efficiently than management? Was management simply irrational? Was management playing the "good guy," unwilling to strike back at worker quasi-rents in the face of union demands for capital quasi-rents?

Finally, are there other explanations of increasing union wage premiums? I believe that there are, especially if we do not require a single theory for all the sectors. The one that I have suggested puts more stress on analyzing the contractual nature of the bargaining process. Although the traditional approach is to look at union-management contracts as a discrete version of the spot labor market that must be negotiated de novo, this is a mistake. Contract expirations are not really the end of the contract. Rather, they are complicated reopeners. Little of the existing contract is changed. Minor tinkering occurs to reflect new conditions, but the party that wants to change the language, for example to strike the COLA clause, has a difficult job ahead. Changing the language or the structure of the contract is treated as a major challenge and in this sense is more akin to contract breach than to a simple rewriting of an expired contract.

Given uncertainty as to future labor market conditions, the collective bargaining contract apportions the risks between the parties. COLA clauses, in part, work as a device for distributing risk. Given the actual supply shocks that occurred, the COLA clauses forced management to bear the great bulk of the short-run burden. 
A current difficulty facing the collective bargaining parties, however, is how to deal with the resulting shift in relative wages and costs. Facing employment declines, which result in part from the expanding premiums, the parties must renegotiate the basic contract itself. This may be a difficult task, given the utility loss to workers in reducing the premium. But if the unions determine that this is too costly, they must then absorb a long-run adjustment to a lower employment base. In other words, it is only now that unions must decide whether or not to adopt an end game strategy.

\section{General Discussion}

Wayne Vroman reported on his own work analyzing individual union wage settlements over an extended period. Using the resulting data, he has found little or no effect in subsequent settlements of unexpected cost-of-living adjustments: inflationary surprises appear to create permanent windfalls in wages. Although such behavior might be hard to explain in a conventional bargaining model, Vroman found it a plausible cause of the rapid wage increases during the 1970s in manufacturing industries with COLAs, since inflation was repeatedly underpredicted during this period. He suggested that a variable allowing for cost-ofliving adjustments should be included in regressions such as those presented in the Lawrences' paper. Robert Lawrence pointed out that the $C O L$ variable (proportion of workers covered by COLAs) failed to add to the explanatory power of the cross-section equations.

Angus Deaton reasoned that the substitution between union and nonunion labor may be more important in explaining growing wage dispersion than the capital-labor substitution that the authors stressed in their model. He noted that unions have been losing representation and conjectured that the aggressive substitution of nonunion for union workers might be holding down average wages in some industries.

Lawrence Summers found the end game and slow game hypotheses plausible and noted that they appeared to explain historical episodes of large wage increases in coal and railroads when employment was declining in those industries. He also noted that scooping may have worked in reverse when airlines were deregulated and became free to fly anywhere. Although deregulation expanded the demand for labor in the industry, the elasticity of demand also increased and wages declined dramatically. However, Summers also observed that the end game and 
slow game require monopoly power by labor, so that the failure of the unionization variable to help explain wage developments is an important finding against the end game and slow game hypotheses. Robert Lawrence replied that in the sample of industries analyzed, 80 percent of the workers were unionized, so that the variance in unionization by industry may not have been great enough to reveal the importance of unions.

Jeffrey Sachs suggested that the Lawrences' model might help explain rapid wage increases in Europe during the 1970s, though he pointed out important institutional differences among countries that make it difficult to test the model on the basis of distinctions such as union versus nonunion wage gains. In the United Kingdom, for example, the gap between union and nonunion wages widened through 1981 despite weak or declining employment in many unionized industries, a development consistent with the Lawrences' model. In West Germany, by contrast, where many industries' union settlements are formally extended to nonunion firms, there is simply no evidence on unionnonunion differentials. 